\title{
Silurian conodont biostratigraphy of the east-central Appalachian Basin (eastern USA): Re-examination of the C.T. Helfrich Collection
}

\author{
Alyssa M. Bancroft \& Bradley D. Cramer
}

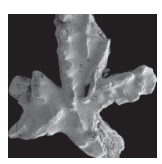

\begin{abstract}
The conodont biozonation for the Silurian succession in the Appalachian Basin was established by C.T. Helfrich nearly half a century ago. Herein, we re-examined and updated the taxonomy of the conodont fauna and the consequent biozonation of the upper Rose Hill, Mifflintown, Wills Creek, and lower Tonoloway formations in the east-central Appalachian Basin. While these strata span the upper Telychian Stage (Llandovery Series) to the upper Pridoli Series, a major stratigraphic gap representing most of the Ludlow Series (from the lower part of the Gorstian to the upper part of the Ludfordian stages) was identified. The new conodont biozonation consists of: the Pterospathodus amorphognathoides amorphognathoides Zonal Group, an Unzoned Interval of the Sheinwoodian Stage, the Kockelella walliseri Zonal Group, the Ozarkodina bicornuta Zone, an Unzoned Interval of the Homerian Stage, the Ozarkodina bohemica Interval Zone, the Ozarkodina crispa Zone, and the Ozarkodina eosteinhornensis sensu lato Interval Zone. This refined biozonation permits enhanced global correlation of the Silurian within the east-central Appalachian Basin. • Key words: Appalachian Basin, Wenlock, Ludlow, Pridoli, conodont biostratigraphy, global zonation, Helfrich collection.
\end{abstract}

Bancroft, A.M. \& Cramer, B.D. 2020. Silurian conodont biostratigraphy of the east-central Appalachian Basin (eastern USA): Re-examination of the C.T. Helfrich Collection. Bulletin of Geosciences 95(1), 1-22 (15 figures). Czech Geological Survey, Prague. ISSN 1214-1119. Manuscript received February 15, 2019; accepted in revised form December 10, 2019; published online February 7, 2020; issued March 31, 2020.

Alyssa M. Bancroft, Indiana Geological and Water Survey, Indiana University, 420 North Walnut Street, Bloomington, Indiana, 47404, USA; ambancro@indiana.edu • Bradley D. Cramer, Department of Earth and Environmental Sciences, University of Iowa, 115 Trowbridge Hall, Iowa City, Iowa, 52245, USA

The largest and stratigraphically most comprehensive collection of conodonts from middle to upper Silurian (uppermost Llandovery-Pridoli series) strata in the Appalachian Basin was produced by Charles T. Helfrich during the 1970's. Most of the work was completed as part of his Ph.D. dissertation (Helfrich 1972) and published in a series of papers (Helfrich 1975, 1978, 1980) that laid the foundation for Silurian conodont biostratigraphy in the Appalachian Basin. In total, more than 15,000 specimens were recovered from six sections in the West Virginia, Virginia, and Maryland tri-state area, with which he established the conodont biozonation for the Silurian succession of the east-central Appalachian Mountains.

Helfrich's work was carried out at the dawn of a major transition in conodont systematics, from form taxonomy to multi-element taxonomy, and relied on the original Silurian conodont biozonation of Walliser (1964) to establish a biostratigraphic zonation for the Appalachian Basin consisting of eight zones for uppermost Llandovery through Pridoli strata. Most reported specimens were identified as form species, typically with tentative multi- element species designations in open nomenclature. Silurian conodont taxonomy and biostratigraphy have advanced tremendously in the intervening decades (e.g., Barrick \& Klapper 1976; Bischoff 1986; Aldridge \& Schönlaub 1989; Kleffner 1989, 1995; Nowlan 1995; Jeppsson 1997; Männik 1998, 2007; Corradini \& Serpagli 1999; Jeppsson \& Aldridge 2000; Calner \& Jeppsson 2003; Murphy et al. 2004; Jeppsson et al. 2006; Carls et al. 2007; Slavík 2014; Corradini et al. 2015; Männik et al. 2015; Mathieson et al. 2016; Waid \& Cramer 2017a, b), however, no modern systematic revision to the conodont biozonation of the uppermost Llandovery to Pridoli interval of the eastcentral Appalachian Basin has been undertaken. Herein, we provide a modern and revised conodont biozonation for the central axis portion of the Appalachian Basin based upon the conodont collection of C.T. Helfrich (Helfrich $1972,1975,1980)$ that was re-examined by the authors at the University of Iowa from 2015-2018. The Helfrich collection is housed at the Museum of Geosciences at Virginia Tech (Virginia Polytechnic Institute and State University). 


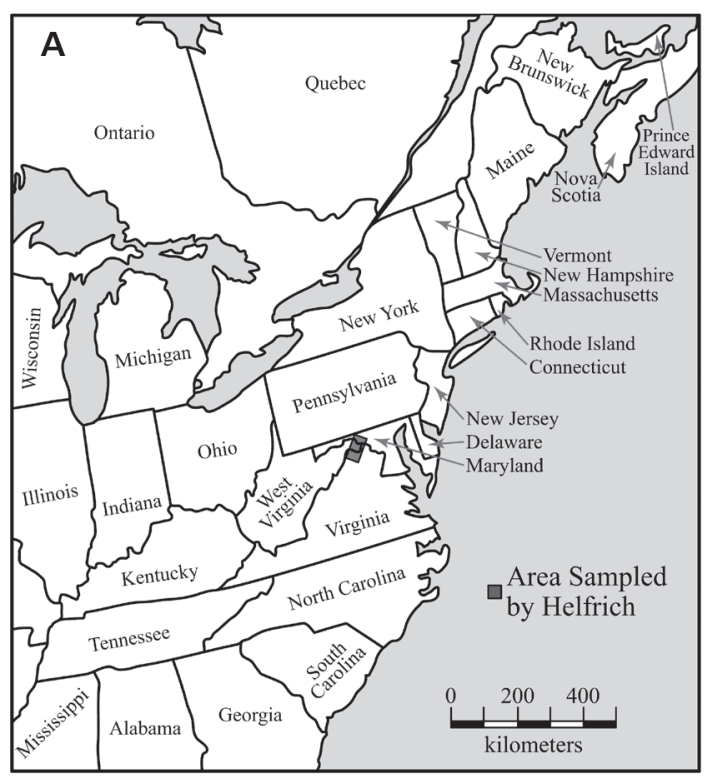

Generalized Silurian Stratigraphy Central Appalachian Mountains from Helfrich $(1972,1975,1978,1980)$

C

\begin{tabular}{|c|c|}
\hline \multirow{2}{*}{\multicolumn{2}{|c|}{ New Creek Formation }} \\
\hline & \\
\hline \multicolumn{2}{|c|}{ Tonoloway Formation } \\
\hline \multicolumn{2}{|c|}{ Wills Creek Formation } \\
\hline \multicolumn{2}{|c|}{$\begin{array}{c}\text { Williamsport Formation } \\
\text { Bloomsburg Formation }\end{array}$} \\
\hline \multirow{3}{*}{ 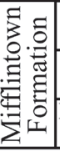 } & McKenzie Member \\
\hline & Cosner Gap Member \\
\hline & $\begin{array}{l}\text { ower HematiticMember } \\
\text { [Keefer Member] }\end{array}$ \\
\hline \multicolumn{2}{|c|}{ Rose Hill Formation } \\
\hline \multicolumn{2}{|c|}{ Tuscarora Formation } \\
\hline
\end{tabular}

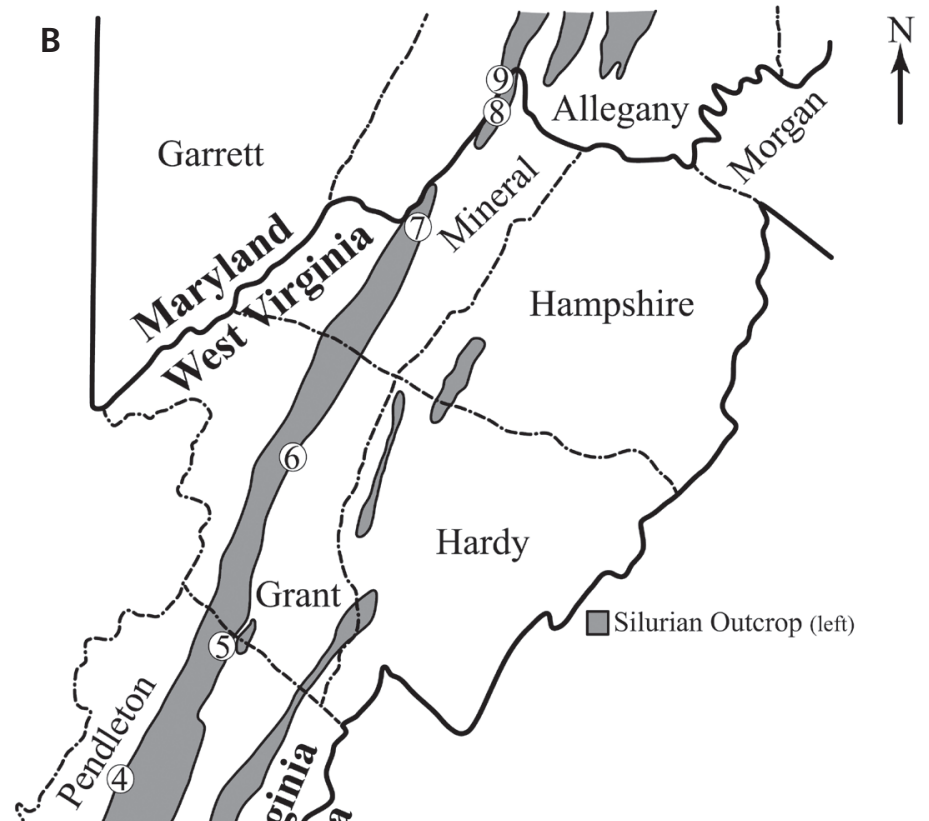

Sampling Localities of Helfrich and Publication Year

1 Strait Creek (1978)

2 Crabbottom $(1972,1975,1980)$

3 Moyer Gap (1972, 1975, 1980)

4 Judy Gap (1972, 1975)

5 Smoke Hole (1978)

6 Cosner Gap (1972, 1975, 1980)

7 Keyser Reservoir (1972, 1975, 1980)

8 Keyser Quarry (1978)

9 Pinto $(1972,1975,1980)$

Figure 1. A - general map of eastern North America, the area Helfrich sampled (Virginia, West Virginia, and Maryland) is highlighted. $\bullet$ B - outcrop map of Silurian strata in the east-central Appalachian Basin showing localities included in the collection. $\bullet \mathrm{C}-$ lithostratigraphic chart showing formations included in the investigation and the dates of publication for manuscripts associated with the collection (the 1972 publication is Helfrich's dissertation document, which was published in 1975 as Geological Society of America Special Paper 161). Modified from Helfrich (1975).

\section{Geologic Setting}

The successive accretion of island arcs and continental fragments onto the eastern margin (present orientation) of the Laurentian paleocontinent from the Ordovician through Devonian provided sufficient flexural subsidence and the creation of accommodation space for extensive Silurian deposition along an area several thousand kilometers long, stretching from Nova Scotia in the north to North Carolina, South Carolina, Georgia, and Alabama in the south (e.g., Hibbard 2000, Ettensohn \& Brett 2002, Van Staal et al. 2014, Pinet 2016). This series of collisional tectonic events, variably termed the Taconic,
Salinic, and Acadian orogenies (Goodman \& Brett 1994, Ettensohn \& Brett 2002, Cramer et al. 2011a, Van Staal et al. 2014), produced the Appalachian Foreland Basin that recorded nearly the entire Silurian succession (e.g., Horvath 1969, Berry \& Boucot 1970, Goodman \& Brett 1994, Brett et al. 1995, Sullivan et al. 2016). The area originally studied by Helfrich (1972) follows the Silurian outcrop belt (Fig. 1) where the states of West Virginia, Virginia, and Maryland converge. This narrow belt was likely on the highland-proximal side of the basin axis during the Silurian (Goodman \& Brett 1994, Sullivan et al. 2016) and is much more clastic rich than the carbonatedominated western margin of the basin. 


\begin{tabular}{|c|c|}
\hline $\begin{array}{c}\text { European } \\
\text { Conodont Zones } \\
\text { (Walliser - 1964) }\end{array}$ & $\begin{array}{c}\text { North American } \\
\text { Conodont Zones } \\
\text { (Nicoll \& Rexroad - 1968) } \\
\text { (Pollock, Rexroad, \& Nicoll - 1970) } \\
(\text { Helfrich - 1975) }\end{array}$ \\
\hline eosteinhornensis & $\begin{array}{c}\text { Spathognathodus } \\
\text { steinhornensis eosteinhornensis }\end{array}$ \\
\hline crispus & Spathognathodus crispus \\
\hline latialatus & Spathognathodus tillmani \\
\hline siluricus $\backslash \begin{array}{l}\text { snajdri } \\
\text { horizon }\end{array}$ & Spathognathodus snajdri \\
\hline ploeckensis & Unzoned Interval \\
\hline crassa & Spathognathodus bicornutus \\
\hline sagitta & $\begin{array}{l}\text { Spathognathodus } \\
\text { sagitta bohemicus }\end{array}$ \\
\hline patula & unreported \\
\hline amorphognathoides & $\begin{array}{c}\text { Pterospathodus } \\
\text { amorphognathoides - } \\
\text { Spathognathodus ranuliformis } \\
\text { (1968) }\end{array}$ \\
\hline celloni & $\begin{array}{l}\text { Neospathognathodus } \\
\text { celloni (1968) }\end{array}$ \\
\hline \multirow{2}{*}{ Bereich I } & Icriodina irregularis (1968) \\
\hline & Panderodus simplex (1970) \\
\hline
\end{tabular}

Flgure 2. Comparison of European (Walliser 1964) and North American conodont biozones used by Helfrich (1975). Figure modified from Helfrich (1975).

\section{Silurian Conodont Biozonation}

Walliser (1964) produced the first recognizably modern conodont biozonation scheme for the Silurian System based primarily upon sections in the Carnic Alps region of Central Europe. The two decades that followed Walliser's original work transformed our understanding of conodont paleobiology, and as a result, also transformed the practice of conodont biostratigraphy (e.g., Sweet \& Bergström 1970, Aldridge \& von Bitter 2009). The transition from form taxonomy to multi-element taxonomy had already begun by the time of Helfrich's doctoral work in the early 1970's, and some of the earliest efforts towards erecting a North American Conodont Zonation had recently been completed (Nicoll \& Rexroad 1968, Pollock

\begin{tabular}{|c|c|c|c|c|c|}
\hline 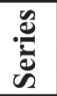 & 总 & $\begin{array}{c}\text { Cramer } \\
\text { et al. (2011b) }\end{array}$ & $\begin{array}{c}\text { Corradini } \\
\text { et al. }(\mathbf{2 0 1 5}) \\
\text { Cellon }\end{array}$ & $\begin{array}{l}\text { McAdams } \\
\text { et al. (2019) }\end{array}$ & $\begin{array}{l}\text { This Study } \\
\text { Appalachian } \\
\text { Basin }\end{array}$ \\
\hline \multirow{3}{*}{ : } & & \multirow{2}{*}{$\begin{array}{l}\text { Ou. elegans } \\
\text { detortus }\end{array}$} & $\begin{array}{c}\text { Upper Ou.el. } \\
\text { detortus }\end{array}$ & \multirow{2}{*}{$\begin{array}{l}\text { Ou. elegans } \\
\text { detortus }\end{array}$} & \\
\hline & & & $\begin{array}{c}\text { Lower Ou.el. } \\
\text { detortus }\end{array}$ & & \\
\hline & & $\begin{array}{l}\text { Oz. eostein- } \\
\text { hornensis s.l. } \\
\text { Interval Zone }\end{array}$ & \begin{tabular}{|c|} 
Oz. eostein- \\
hornensis s.l. \\
Interval Zone \\
\end{tabular} & \begin{tabular}{|c|} 
Oz. eostein- \\
hornensis s.l. \\
Interval Zone
\end{tabular} & $\begin{array}{c}\text { Oz. eostein- } \\
\text { hornensis s.l. } \\
\text { Interval Zone }\end{array}$ \\
\hline \multirow{6}{*}{$\frac{3}{2}$} & \multirow{4}{*}{ 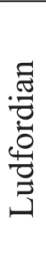 } & Oz. crispa & Oz. crispa & Oz. crispa & Oz. crispa \\
\hline & & $\begin{array}{l}\text { Oz. snajdri } \\
\text { Interval Zone }\end{array}$ & $\begin{array}{c}\text { Oz. snajdri/ } \\
\text { Ped. latialata } \\
\text { Interval Zone }\end{array}$ & $\begin{array}{c}\text { Oz. snajdri/ } \\
\text { Ped. latialata } \\
\text { Interval Zone }\end{array}$ & \\
\hline & & Po. siluricus & Po. siluricus & Po. siluricus & \\
\hline & & A. ploeckensis & A. ploeckensis & A. ploeckensis & \\
\hline & \multirow{2}{*}{ 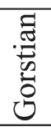 } & $\begin{array}{l}\text { K. variabilis } \\
\text { Interval Zone }\end{array}$ & $\begin{array}{l}\text { K. variabilis } \\
\text { Interval Zone }\end{array}$ & $\begin{array}{l}\text { K. variabilis } \\
\text { Interval Zone }\end{array}$ & \\
\hline & & K. crassa & K. crassa & K. crassa & \\
\hline \multirow{6}{*}{$\frac{y}{0}$} & \multirow{3}{*}{ 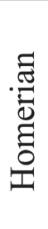 } & $\begin{array}{l}K . \text { ortus } \\
\text { absidata }\end{array}$ & & $\begin{array}{l}K . \text { ortus } \\
\text { absidata }\end{array}$ & \multirow{2}{*}{$\begin{array}{c}\text { Oz. } \\
\text { bohemica } \\
\text { Interval Zone }\end{array}$} \\
\hline & & $\begin{array}{c}\text { Oz. bohemica } \\
\text { longa }\end{array}$ & & $\begin{array}{c}\text { Oz. bohemica } \\
\text { longa }\end{array}$ & \\
\hline & & $\begin{array}{l}\text { Oz. sagitta } \\
\text { sagitta }\end{array}$ & $\begin{array}{l}\text { Oz. sagitta } \\
\text { sagitta }\end{array}$ & $\begin{array}{l}\text { Oz. sagitta } \\
\text { sagitta }\end{array}$ & $\begin{array}{l}\text { Unzoned } \\
\text { Interval }\end{array}$ \\
\hline & \multirow{3}{*}{$\begin{array}{l}\frac{\pi}{7} \\
8 \\
0 \\
\frac{3}{0} \\
\frac{2}{\sqrt{2}}\end{array}$} & K. ortus ortus & K. ortus ortus & \multirow{2}{*}{$\begin{array}{c}\text { K. amsdenif } \\
\text { K. walliseri } \\
\text { Superzone }\end{array}$} & Oz. bicornuta \\
\hline & & \multirow{2}{*}{\begin{tabular}{|l|} 
K. walliseri \\
Oz. s. rhenana \\
$\begin{array}{c}\text { K. ranuliformis } \\
\text { Superzone }\end{array}$ \\
Pt.p.pro. S.Z. \\
\end{tabular}} & \multirow[t]{2}{*}{ K. patula } & & \begin{tabular}{|l} 
K. walliseri \\
Zonal Group
\end{tabular} \\
\hline & & & & \begin{tabular}{|l} 
Oz. s. rhenana \\
K. ranuliformis \\
Superzone \\
Pt. p. pro. S.Z.
\end{tabular} & $\begin{array}{l}\text { Unzoned } \\
\text { Interval }\end{array}$ \\
\hline 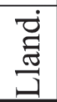 & $\frac{\overrightarrow{2}}{0}$ & $\begin{array}{l}\text { Pt. am. } \\
\text { amorph. } \\
\text { Zonal Group }\end{array}$ & $\begin{array}{l}\text { Pt. am. } \\
\text { amorph. }\end{array}$ & $\begin{array}{c}\text { Pt. am. } \\
\text { amorph. } \\
\text { Zonal Group }\end{array}$ & $\begin{array}{l}\text { Pt. am. } \\
\text { amorph. } \\
\text { Zonal Group }\end{array}$ \\
\hline
\end{tabular}

Figure 3. Comparison of conodont biozonations used by Cramer et al. (2011b), Corradini et al. (2015), McAdams et al. (2019), and this study. Cramer et al. (2011b) and McAdams et al. (2019) were intended to be global biostratigraphic charts. Corradini et al. (2015) shows the biozonation they developed for the classical Cellon Section in the Carnic Alps. The grey areas denote missing stratigraphic section and we followed this in our column at the far right. Where section is clearly missing, we have a gray area. Where strata exist but are devoid of biostratigraphically important specimens, we refer to it as an Unzoned Interval. Abbreviations: Lland. - Llandovery; Tely. - Telychian; A. Ancyrodella; am. or amorph. - amorphognathoides; el. - elegans; K. Kockelella; o. - ortus; Ou. - Oulodus; Oz. - Ozarkodina; . - pennatus; P. - Polygnathoides; Ped. - Pedavis; pro. - procerus; Pt. - Pterospathodus; s. - sagitta; s.l. - sensu lato; I.Z. - Interval Zone; S.Z. Superzone.

et al. 1970). Helfrich (1972) added to these studies and erected a new suite of conodont biozones for the upper Llandovery, Wenlock, Ludlow, and Pridoli series of North America (Fig. 2). Since that time, considerable progress has been made integrating global advances in conodont biostratigraphy into Silurian chronostratigraphy of North America (see discussion in Cramer et al. 2011b). With the exception of a handful of studies (e.g., Denkler \& Harris 1988a, b; Kleffner et al. 2009) however, most 


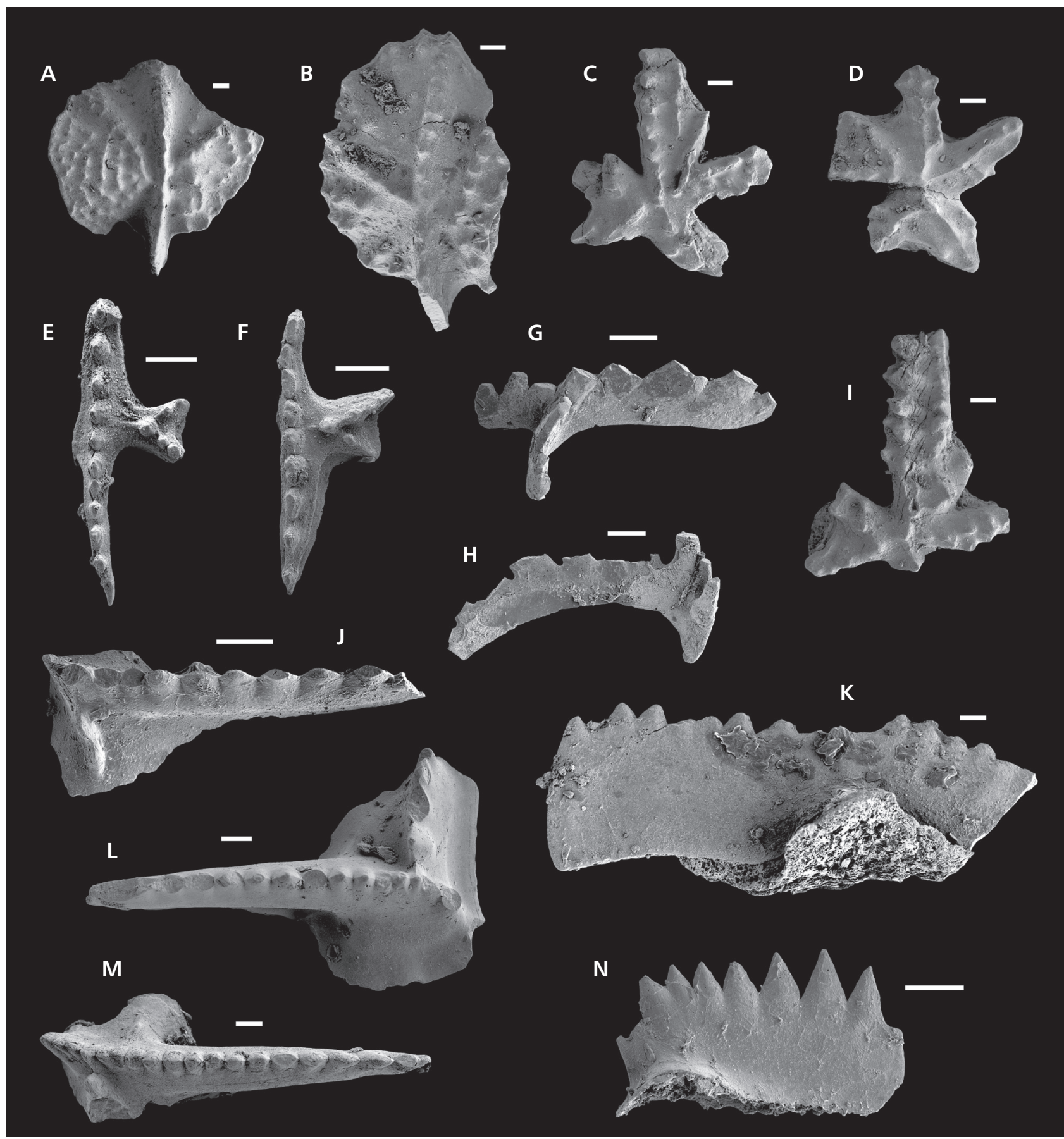

Figure 4. A, B - Apsidognathodus tuberculatus Walliser, 1964; A - Cosner Cap Section, Rose Hill Formation (CG-RH1) [VPIL 3706] (Helfrich 1980, pl. 1, fig. 29); B - Cosner Cap Section, Rose Hill Formation (CG-RH1) [VPIL 3754]. C C, D, I - Distomodus staurognathoides (Walliser, 1964); C - Pinto Section, Rose Hill Formation (P-RH5) [VPIL 3698] (Helfrich 1980, pl. 1, fig. 22); D - Pinto Section, Rose Hill Formation (P-RH5) [VPIL 4764]; I - Pinto Section, Rose Hill Formation (P-RH5) [VPIL 4764]. • E, F - Pterospathodus amorphognathoides amorphognathoides Walliser, 1964; E - Keyser Reservoir Section, Rose Hill Formation (KR-RH4) [VPIL 3722] (Helfrich 1980, pl. 2, fig. 18); F - Keyser Reservoir Section, Rose Hill Formation (KR-RH3) [VPIL 4756]. - G, H - Pseudolonchodina fluegeli fluegeli (Walliser, 1964); G - Keyser Reservoir Section, Rose Hill Formation (KR-RH4) [VPIL 3691] (Helfrich 1980, pl. 1, fig. 11); H - Keyser Reservoir Section, Rose Hill Formation (KR-RH6) [VPIL 3689] (Helfrich 1980, pl. 1, fig. 9). • J -Kockelella ?ranuliformis (Walliser, 1964), Pinto Section, Rose Hill Formation (P-RH1) [VPIL 3722] (Helfrich 1980, pl. 2, figs 15, 16). - Ozarkodina gulletensis (Aldridge, 1972), Moyer Gap Section, Lower Hematitic Member, Mifflintown Formation (MG-LMH1) [VPIL 3753]. L-N - Kockelella walliseri (Helfrich, 1975); L - Cosner Gap Section, Cosner Gap Member, Mifflintown Formation (CG-CG6) [VPIL 1222] holotype (Helfrich 1975, pl. 1, fig. 21); M - Cosner Gap Section, Cosner Gap Member, Mifflintown Formation (CG-CG5) [VPIL 1221] paratype (Helfrich 1975, pl. 1, fig. 19); N - Cosner Gap Section, Cosner Gap Member, Mifflintown Formation (CG-CG1) [VPIL 1218] paratype (Helfrich 1975, pl. 1, fig. 1). Scale bars $=100$ microns. 


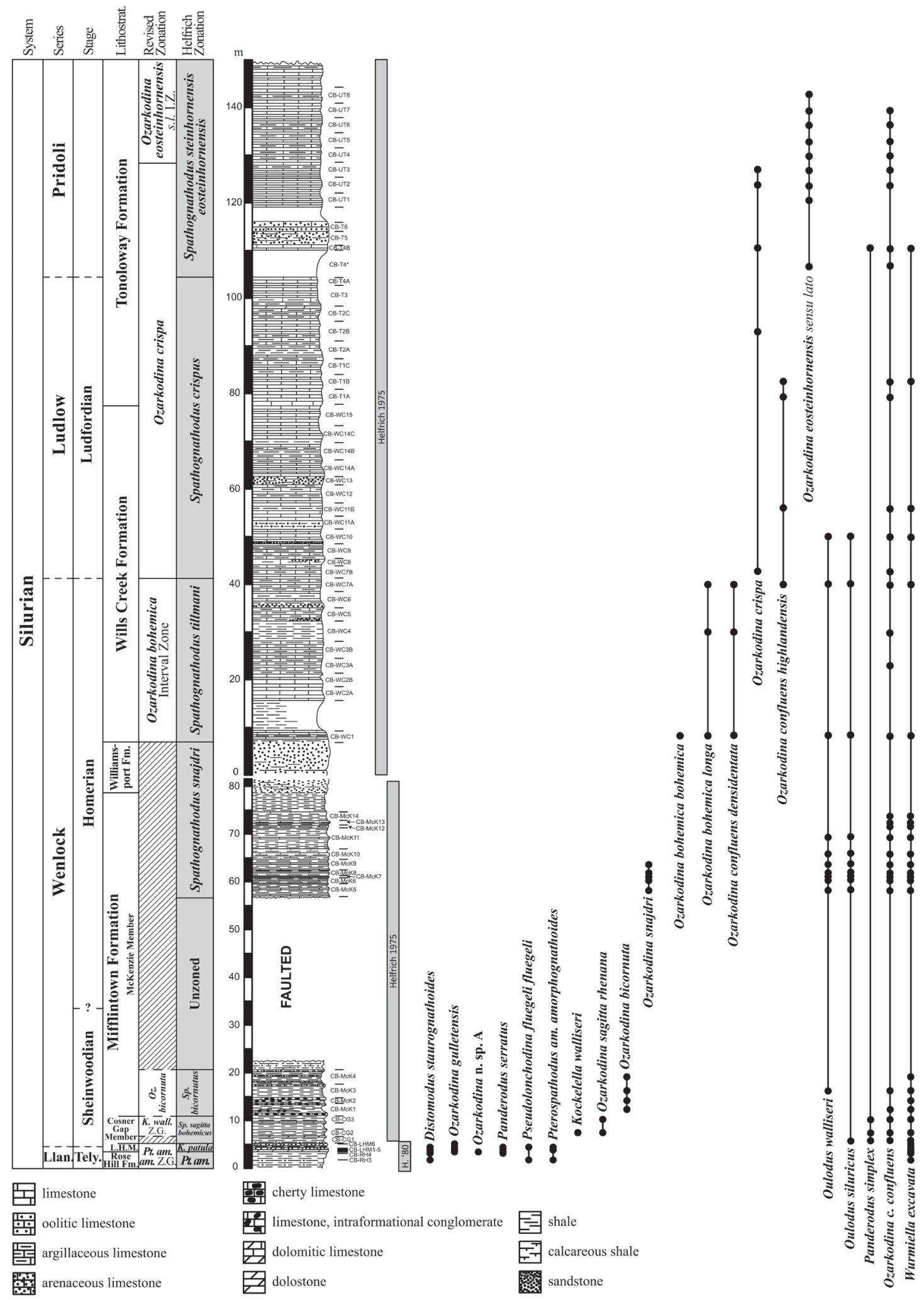

Figure 5. Stratigraphic column for the Crabbottom Section, Highland County, Virginia, combined from Helfrich (1980) and Helfrich (1975). The original biozonations of Helfrich are shown against the new biozonation designations made herein. Lithologic key at the bottom of this figure applies to all other lithologic columns in the manuscript. Diagonal hatching in the biozone column indicates an unzoned interval because of a lack of diagnostic fauna. Abbreviations: Llan. - Llandovery; Tely. - Telychian; Fm. - Formation; L.H.M. - Lower Hematitic Member; am. - amorphognathoides; K. Kockelella; Oz. - Ozarkodina; Pt. - Pterospathodus; s.l. - sensu lato; Sp. - Spathognathodus; wall. - walliseri; I.Z. - Interval Zone; Z.G. - Zonal Group. 


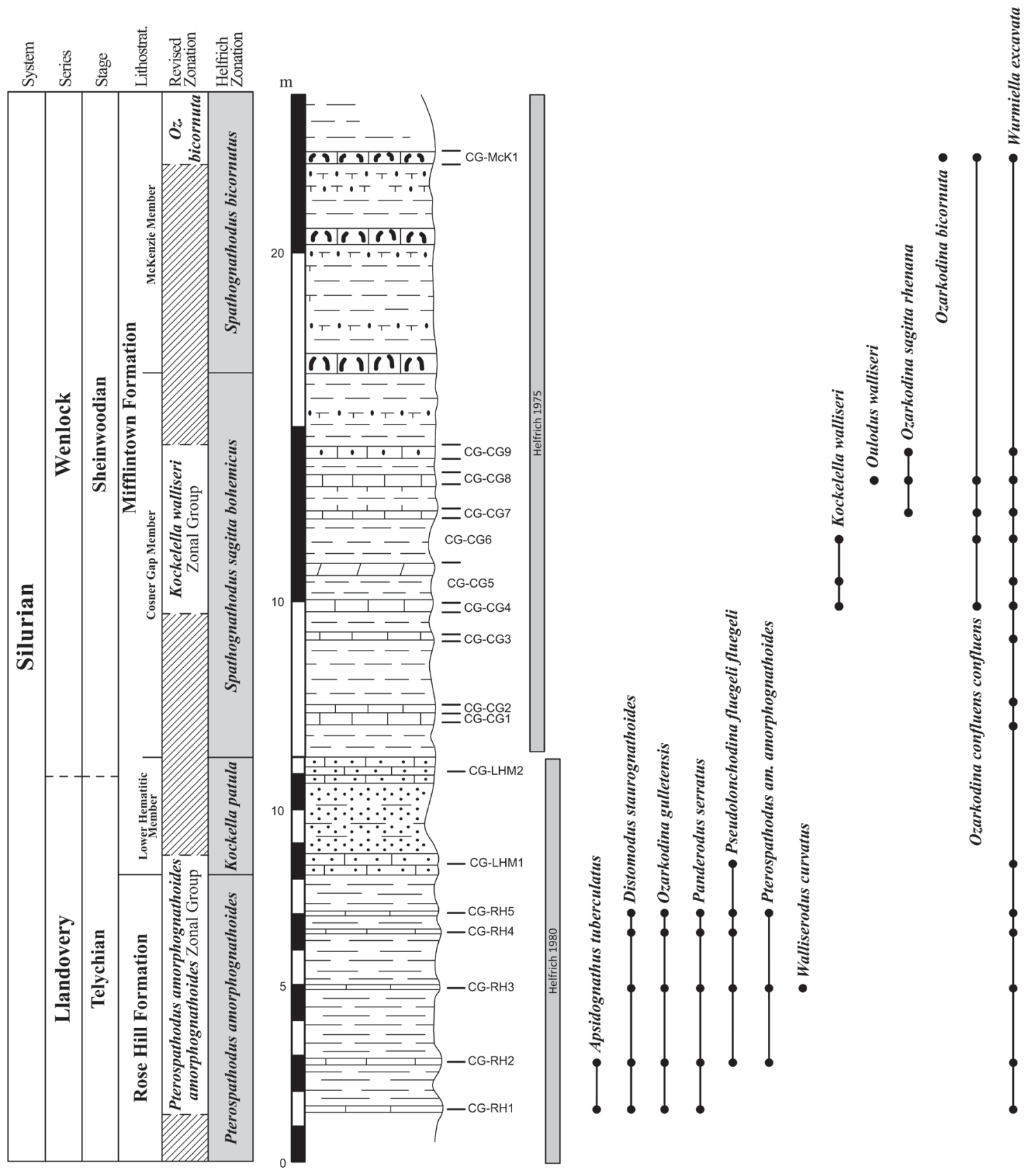

Figure 6. Stratigraphic column for the Cosner Gap Section, Grant County, West Virginia, combined from Helfrich (1980) and Helfrich (1975). The original biozonations of Helfrich are shown against the new biozonation designations made herein. Lithologic key can be found in the caption to Fig. 5 . Diagonal hatching in the biozone column indicates an unzoned interval because of a lack of diagnostic fauna. Abbreviation: Oz. - Ozarkodina.

of the conodont work in North America in the past 50 years has been either limited to the western margin of the Appalachian Basin or outside of the Appalachian Basin altogether. As a result, the placement of modern global Silurian conodont biozones within the strata of the Appalachian Basin remains unclear.

Conodont biozonations established during the past decade advanced our ability to correlate sections globally (e.g., Cramer et al. 2011b), as well as improved our understanding of some of the historically most important Silurian conodont collections (Corradini et al. 2015). Here, we attempt to apply global Silurian conodont biozones (Cramer et al. 2011b, Corradini et al. 2015, McAdams et al. 2019) to the C.T. Helfrich collection from the Appalachian Basin succession (Fig. 3). We provide new and updated occurrence range charts for each outcrop 


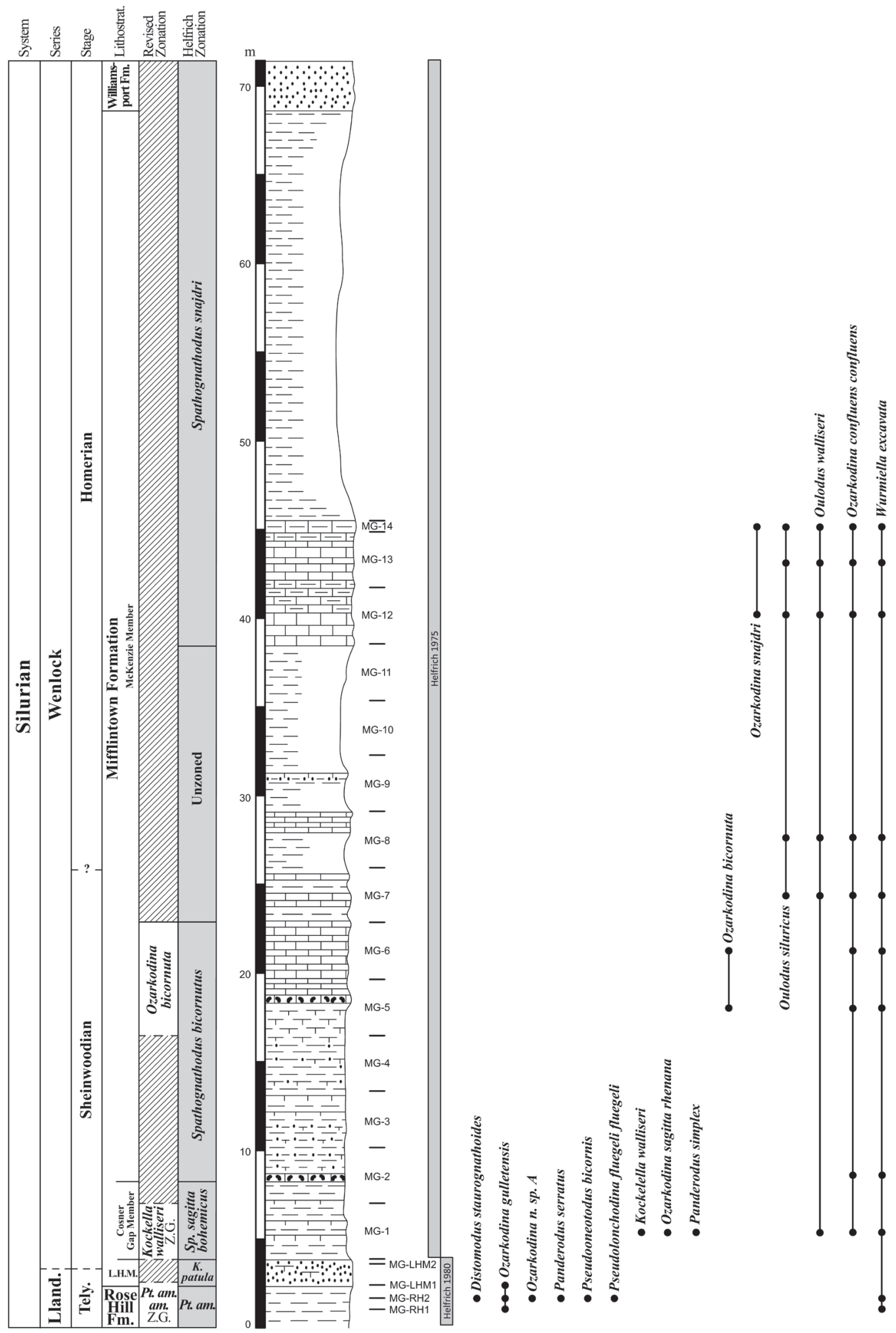

Figure 7. Stratigraphic column for the Moyer Gap Section, Pendleton County, West Virginia, combined from Helfrich (1980) and Helfrich (1975). The original biozonations of Helfrich are shown against the new biozonation designations made herein. Lithologic key can be found in the caption to Fig. 5. Diagonal hatching in the biozone column indicates an unzoned interval because of a lack of diagnostic fauna. Abbreviations: Lland. Llandovery; Tely. - Telychian; Fm. - Formation; L.H.M. - Lower Hematitic Member; am. - amorphognathoides; K. - Kockelella; Pt. - Pterospathodus; Sp. - Spathognathodus; Z.G. - Zonal Group. 
studied, and we re-illustrated a number of specimens included in Helfrich $(1972,1975,1980)$ in addition to new images of material not previously illustrated from the collection. The result is an improved global correlation that considerably alters the chronostratigraphic position of strata within the Appalachian Basin.

\section{Pterospathodus amorphognathoides amorphognathoides Zonal Group (Jeppsson 1997)}

The Pterospathodus amorphognathoides amorphognathoides Zonal Group consists of a series of zones as originally defined by Jeppsson (1997) that are effectively the taxon-range zone for Pt. am. amorphognathoides. This zonal group occurs throughout the studied sections in the uppermost part of the Rose Hill Formation and extends through most, if not all, of the Lower Hematitic Member (LHM) of the Mifflintown Formation. The Pt. am. amorphognathoides Zonal Group in the study area contains the eponymous species, Distomodus staurognathoides, Ozarkodina gulletensis, Pseudolonchodina fluegeli fluegeli, and Apsidognathus tuberculatus (Fig. 4). The upper boundary of the zone should be placed no higher than the top of the LHM of the Mifflintown Formation.

Helfrich $(1975,1980)$ correlated the LHM with the Kockelella patula conodont Biozone of Walliser (1964) not based on the presence of K. patula, but because this interval was, in part, above the disappearance of Pt. am. amorphognathoides and below what he identified as Ozarkodina sagitta bohemica in the overlying Cosner Gap Member of the Mifflintown Formation. Pt. am. amorphognathoides disappears in all sections below the top of the LHM. The highest occurrence is in the second to highest sample in the Crabbottom locality (Fig. 5). However, because many sections did not include continuous sampling through the LHM or had very poor conodont yields owing to the clastic-rich nature of the strata, it is difficult to determine the precise position.

\section{Unzoned Interval of the Sheinwoodian Stage}

From the disappearance of Pt. am. amorphognathoides to the first appearance of Kockelella walliseri there are no zonally diagnostic conodonts in the studied collection utilizing current biozonal schemes. The typical globally recognized zonal indicators (Fig. 3) Pterospathodus pennatus procerus and Kockelella ranuliformis were not recovered, and although Ozarkodina sagitta rhenana does occur in the collection, its first occurrence is either stratigraphically above or coeval with the first occurrence of $K$. walliseri in all sections where they co-occur (Crabbottom - Fig. 5, Cosner Gap - Fig. 6, Moyer Gap - Fig. 7). Based upon the disappearance of Distomodus staurognathoides it is most likely that this interval belongs to the Upper $K$. ranuliformis Zone and the $O z$. s. rhenana Zone of Jeppsson (1997). However, because of the lack of the diagnostic taxa we have chosen to designate this as an Unzoned Interval. This interval spans the uppermost Lower Hematitic Member to the lowermost Cosner Gap Member of the Mifflintown Formation.

\section{Kockelella walliseri Zonal Group (modified from Jeppsson 1997)}

The taxon-range zone for Kockelella walliseri was defined as the K. walliseri Zonal Group (Jeppsson 1997) to include four zones based upon the overlap and disappearance of $O z$. sagitta rhenana and $K$. patula within the range of $K$. walliseri. This zonal group occurs throughout the remainder of the Cosner Gap Member of the Mifflintown Formation. The lower boundary of the zone is placed at the base of the first appearance of $K$. walliseri (see Cramer et al. 2010) and the upper boundary is placed at the last appearance of $O z$. s. rhenana. Strictly speaking, this is the definition of the Lower $K$. walliseri Zone of Jeppsson (1997). However, under Jeppsson's original range definitions, Oz. s. rhenana should appear before K. walliseri and disappear before the last appearance datum (LAD)

Figure 8. A-C - Ozarkodina bicornuta (Helfrich, 1975); A - Crabbottom Section, McKenzie Member, Mifflintown Formation (CB-McK3) [VPIL 1117] holotype (Helfrich 1975, pl. 1, fig. 11); B - Cosner Gap Section, McKenzie Member, Mifflintown Formation (CG-McK1) [VPIL 1119] paratype (Helfrich 1975, pl. 1, fig. 14); C - Keyser Reservoir Section, McKenzie Member, Mifflintown Formation (KR-McK5) [VPIL 1120] paratype (Helfrich 1975, pl. 1, fig. 15). D-Q - Ozarkodina sagitta rhenana (Walliser, 1964); D - Cosner Gap Section, Cosner Gap Member, Mifflintown Formation (CG-CG7) [VPIL 13622FF]; E - Cosner Gap Section, Cosner Gap Member, Mifflintown Formation (CG-CG7) [VPIL 1362]; F - Cosner Gap Section, Cosner Gap Member, Mifflintown Formation (CG-CG7) [VPIL 1362FF]; G - Cosner Gap Section, Cosner Gap Member, Mifflintown Formation (CG-CG2) [VPIL 1357]; H - Cosner Gap Section, Cosner Gap Member, Mifflintown Formation (CG-CG2) [VPIL 1357]; I - Cosner Gap Section, Cosner Gap Member, Mifflintown Formation (CG-CG7) [VPIL 1362]; J - Cosner Gap Section, Cosner Gap Member, Mifflintown Formation (CG-CG7) [VPIL 1362]; K - Cosner Gap Section, Cosner Gap Member, Mifflintown Formation (CG-CG7) [VPIL 1362]; L - Moyer Gap Section, Cosner Gap Member, Mifflintown Formation (MG-CG5) [VPIL 1340]; M - Cosner Gap Section, Cosner Gap Member, Mifflintown Formation (CG-CG2) [VPIL 1357]; N - Cosner Gap Section, Cosner Gap Member, Mifflintown Formation (CG-CG2) [VPIL 1357];O - Cosner Gap Section, Cosner Gap Member, Mifflintown Formation (CG-CG7) [VPIL 1362]; P - Moyer Gap Section, Cosner Gap Member, Mifflintown Formation (MG-CG5) [VPIL 1177] (Helfrich 1975, pl. 1, fig. 3); Q - Crabbottom Section, Cosner Gap Member, Mifflintown Formation (CB-CG2) [VPIL 987] (Helfrich 1975, pl. 4, fig. 1). Scale bars = 100 microns. 


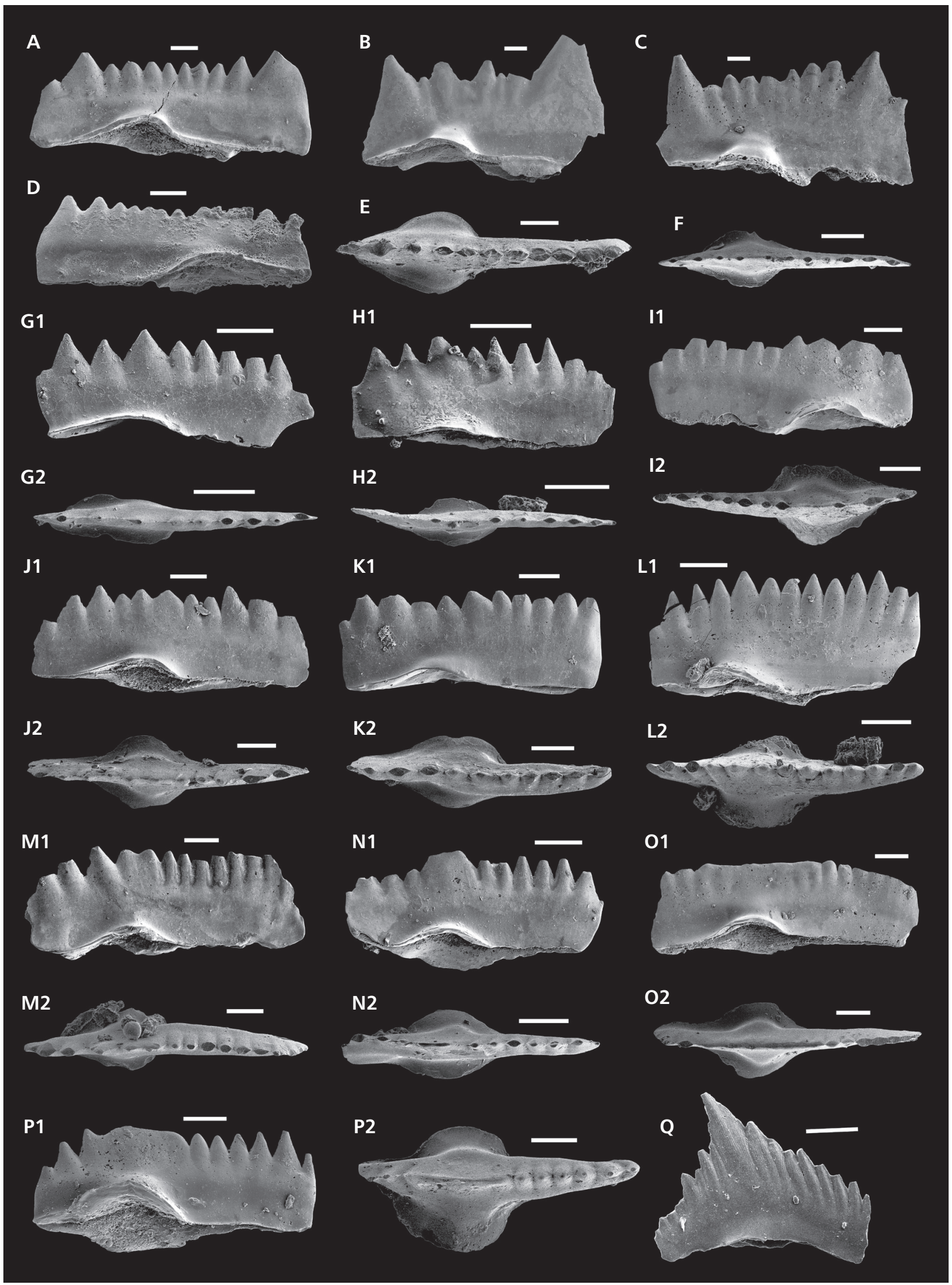


of $K$. walliseri. Neither of these two orders of events are true in the studied sections, and the range of $O z$. s. rhenana extends above $K$. walliseri in several sections. We therefore consider this a likely upwards range extension of $O z$. s. rhenana and mark the top of this Zonal Group at the highest occurrence of either $K$. walliseri or $O z$. s. rhenana (Oz. s. rhenana in the studied sections).

Jeppsson (1997), based on the published photographs in Helfrich (1975), clearly identified that the specimens Helfrich (1975) referred to as Spathognathodus sagitta bohemicus were not the same species as Walliser's (1964) Sp. s. bohemicus. Jeppsson (1997, p. 101) also pointed out that specimens closely similar to those illustrated as Sp. s. bohemicus by Helfrich (1975) occur on Gotland, Sweden, within the Oz. sagitta rhenana Biozone, that Aldridge (1985) illustrated a similar early Sheinwoodian subspecies from the United Kingdom, and that due to the co-occurrence with $K$. walliseri in his sections, Helfrich's (1975) specimens do not indicate a placement within the Homerian Stage. We agree with Jeppsson (1997) that the zone identified by Helfrich (1975) as Sp. sagitta bohemicus should instead be referred to the $K$. walliseri Zonal Group.

The taxonomic definitions of Walliser's (1964) original subspecies of Spathognathodus sagitta leave much to be desired. Originally designated as Spathognathodus sagitta rhenanus, Spathognathodus sagitta sagitta, and Spathognathodus sagitta bohemicus, they have since all been placed within the genus Ozarkodina (see Aldridge 1975), however, their diagnoses remain imprecise and overlap to a great extent. As the name implies, one of the major diagnostic features is an arrow-shaped outline in oral view. Walliser $(1964$, p. 83) originally stated that $O z$. s. rhenana usually contained 9 to 16 denticles, $O z$. s. sagitta contained 15 to 22 denticles, and that $O z$. s. bohemica was "approximately between the two others, as far as development of the denticles is concerned. The blade is relatively high in relation to the length." Jeppsson in Calner \& Jeppsson (2003) elevated bohemica to a species designation and erected a new subspecies, Ozarkodina bohemica longa, which could be differentiated from Ozarkodina bohemica bohemica based on its overall blade length to blade height ratio.

Several samples in the studied collection contain abundant specimens originally referred to as Sp. sagitta bohemicus. Many are clearly $\mathrm{Oz}$. sagitta rhenana and have an obvious arrow-shaped basal cavity in oral view and bear 10 to 12 denticles (Fig. 8, specimens D-F, I). However, specimens in these collections, particularly those from Cosner Gap and Moyer Gap (samples CG-CG2, CG-CG7, and MG-CG5), contain an unexpected range of variability. In particular, there is a wide range of both spatulate and denticulate forms in addition to extensive variation in the placement of the basal cavity from fully posterior to nearly central (Fig. 8, specimens J-P). Almost all samples that yielded $O z$. s. rhenana also contain what Helfrich (1975) referred to as a new subspecies Ozarkodina edithae marie (Fig. 8Q). As early as Walliser (1964, p. 83) it was generally accepted that Ozarkodina edithae was part of the same "conodont assemblage" as Sp. sagitta, and we now consider the form element Oz. edithae to be the $\mathrm{P}_{2}$ element of $\mathrm{Oz}$. sagitta (Aldridge 1972). Within the population of $O z$. s. rhenana recovered from the east-central Appalachian Basin there are also multiple examples of extremely unique forms as well (Fig. 9A-C).

\section{Ozarkodina bicornuta Zone (Helfrich 1975)}

Originally defined as the taxon-range zone for Spathognathodus bicornutus (Helfrich 1975), this species (Fig. $8 \mathrm{~A}-\mathrm{C}$ ) appears to have been endemic to the central Appalachian Basin. With the exception of a single report of Ozarkodina aff. bicornuta from the Homerian of Estonia (Viira \& Aldridge 1998), this species has not been illustrated outside of the Helfrich collection. Here, we also use this zone primarily because of the lack of other zonally diagnostic conodonts in this interval (e.g., Kockelella patula, Kockelella ortus ortus, Ozarkodina sagitta sagitta). The base of this zone was placed at the base of the McKenzie Member of the Mifflintown Formation by Helfrich, but $\mathrm{Oz}$. bicornuta only occurs this low in one (Crabbottom - Fig. 5) of the four outcrops from which it was recovered (Cosner Gap - Fig. 6, Moyer Gap - Fig. 7, Keyser Reservoir - Fig. 10). This zone appears to be correlative to the upper part of the K. walliseri/K. amsdeni Superzone and the lowermost part of the Oz. sagitta sagitta Zone of McAdams et al. (2019). This zone corresponds with the uppermost part of the Sheinwoodian Stage and

Figure 9. A-C - Ozarkodina sp. (?rhenana); A - Moyer Gap Section, Cosner Gap Member, Mifflintown Formation (MG-CG5) [VPIL 1182] (Helfrich 1975, pl. 1, fig. 20); B - Moyer Gap Section, Cosner Gap Member, Mifflintown Formation (MG-CG5) [VPIL 1340]; C - Moyer Gap Section, Cosner Gap Member, Mifflintown Formation (MG-CG5) [VPIL 1340]. D-F - Ozarkodina snajdri (Walliser, 1964); D - Crabbottom Section, McKenzie Member, Mifflintown Formation (CB-McK7B) [VPIL 1318]; E - Crabbottom Section, McKenzie Member, Mifflintown Formation (CB-McK7) [VPIL 1186] (Helfrich 1975, pl. 2, fig. 11); F - Crabbottom Section, McKenzie Member, Mifflintown Formation (CB-McK7A) [VPIL 1191] (Helfrich 1975, pl. 2, fig. 17). $・ \mathrm{G}$ - Ozarkodina bohemica bohemica (Walliser, 1964), Crabbottom Section, Will Creek Formation (CB-WC1DUB) [VPIL 1213] (Helfrich 1975, pl. 13, fig. 6 - holotype of Spathognathodus tillmani). $\cdot \mathrm{H}-\mathrm{K}-; \mathrm{H}$ - Crabbottom Section, Will Creek Formation (CB-WC1) [VPIL 1217] (Helfrich 1975, pl. 13, fig. 11 - paratype of Spathognathodus tillmani); I - Crabbottom Section, Will Creek Formation (CB-WC1D) [VPIL 1391]; 


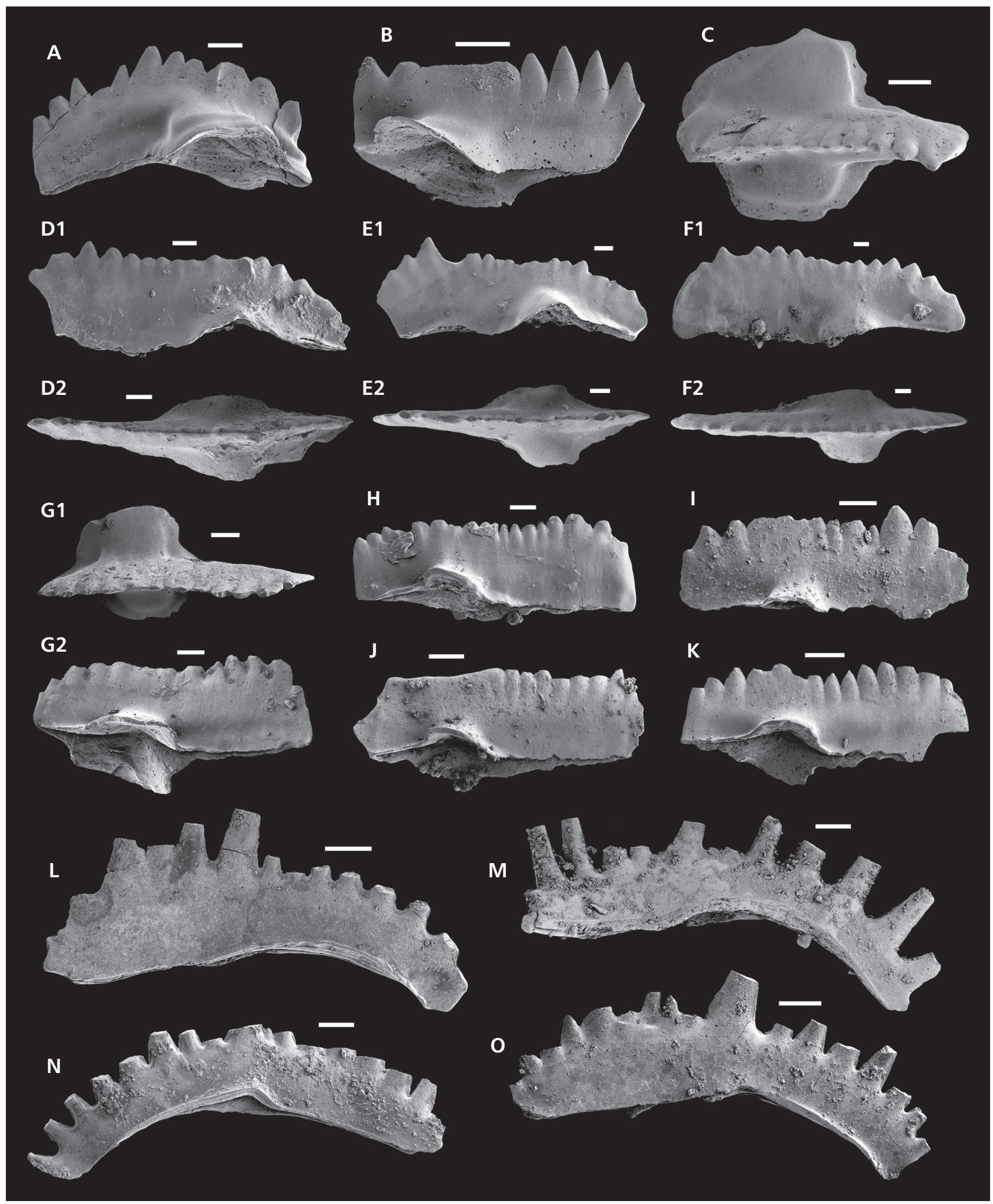

J - Crabbottom Section, Will Creek Formation (CB-WC1D) [VPIL 1209] (Helfrich 1975, pl. 13, fig. 1 - paratype of Spathognathodus tillmani); K - Crabbottom Section, Will Creek Formation (CB-WC1D) [VPIL 1210] (Helfrich 1975, pl. 13, fig. 2 - Ozarkodina bohemica longa Jeppsson in Calner \& Jeppsson, 2003, paratype of Spathognathodus tillmani). $\bullet$ L-O - ? Ozarkodina sinuosa Helfrich, 1975; L - Crabbottom Section, Will Creek Formation (CB-WC1) [VPIL 1012] paratype (Helfrich 1975, pl. 16, fig. 18); M - Crabbottom Section, Will Creek Formation (CB-WC1DUB) [VPIL 1017] holotype (Helfrich 1975, pl. 16, fig. 30); N - Crabbottom Section, Will Creek Formation (CB-WC1DUB) [VPIL 1016] paratype (Helfrich 1975, pl. 16, fig. 28); O - Crabbottom Section, Will Creek Formation (CB-WC1DUB) [VPIL 1393]. Scale bars $=100$ microns. 


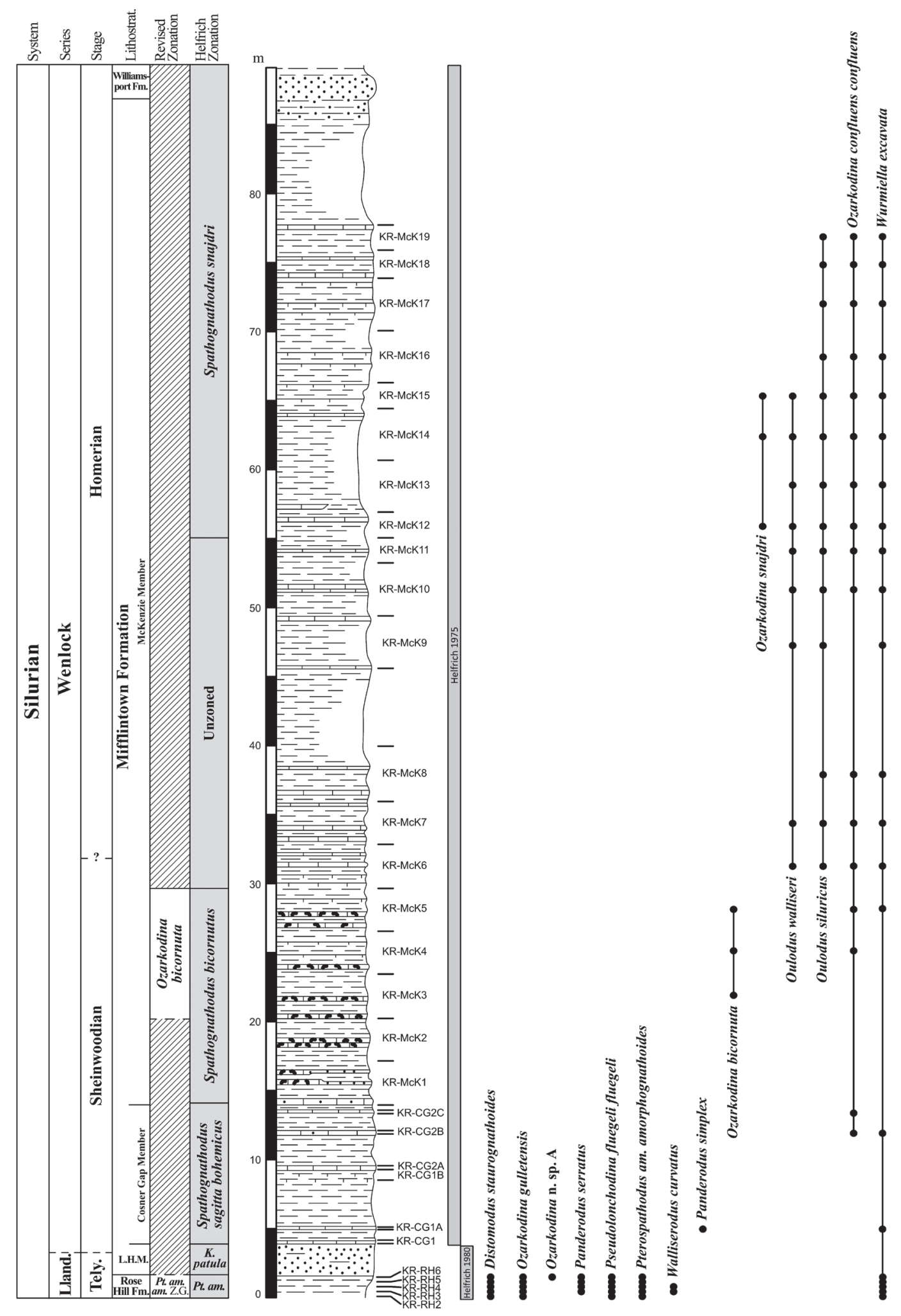

Figure 10. Stratigraphic column for the Keyser Reservoir Section, Mineral County, West Virginia, combined from Helfrich (1980) and Helfrich (1975). The original biozonations of Helfrich are shown against the new biozonation designations made herein. Lithologic key can be found in the caption to Fig. 5. Diagonal hatching in the biozone column indicates an unzoned interval because of a lack of diagnostic fauna. Abbreviations: Lland. - Llandovery; Tely. - Telychian; Fm. - Formation; L.H.M. - Lower Hematitic Member; am. - amorphognathoides; K. - Kockelella; Pt. Pterospathodus; Z.G. - Zonal Group. 


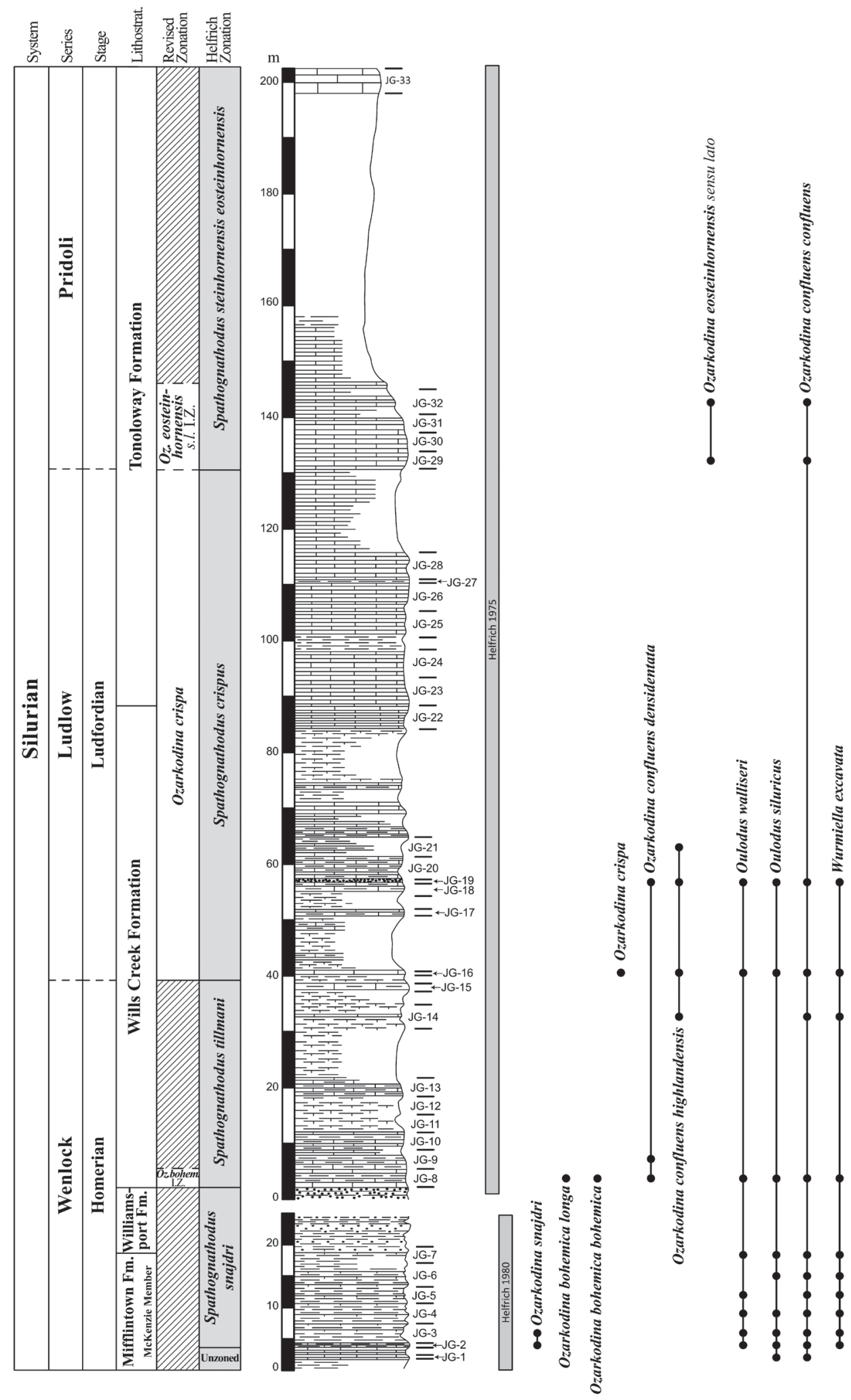

Figure 11. Stratigraphic column for the Judy Gap Section, Pendleton County, West Virginia, combined from Helfrich (1980) and Helfrich (1975). The original biozonations of Helfrich are shown against the new biozonation designations made herein. Lithologic key can be found in the caption to Fig. 5 . Diagonal hatching in the biozone column indicates an unzoned interval because of a lack of diagnostic fauna. Abbreviations: Fm. - Formation; bohem. bohemica; Oz. -Ozarkodina; s.l. - sensu lato; I.Z. - Interval Zone. 
the base of the Homerian Stage is likely above the top of the zone. The long-ranging conodonts Ozarkodina confluens confluens and Wurmiella excavata are often the only other conodonts to co-occur with $\mathrm{Oz}$. bicornuta.

\section{Unzoned Interval of the Homerian Stage}

From the disappearance of Oz. bicornuta to the appearance of Ozarkodina bohemica longa there are no zonally diagnostic conodonts in the studied collection. This interval does contain Ozarkodina snajdri, however, the biostratigraphic utility of $\mathrm{Oz}$. snajdri has been progressively diminished in the past 30 years. Originally defined as a horizon within the Ludfordian Stage of the Ludlow Series by Walliser (1964), it has been used variably as the designator of an $\mathrm{Oz}$. snajdri Zone or the eponymous species for an interval zone, both of which were in the Ludfordian Stage (see review by Corradini et al. 2015). The transition away from the use of $O z$. snajdri as a zonal indicator followed the recognition that its first occurrence was highly variable (Viira \& Aldridge 1998), and it has been found at least as low as the lower Hemse Marl (Jeppsson 2005) within the lower part of the Gorstian Stage. This position is just above the highest occurrence of Ozarkodina bohemica longa on Gotland (Calner \& Jeppsson 2003). Here, we have a further downward range extension of $\mathrm{Oz}$. snajdri to a position below $\mathrm{Oz}$. bohemica longa within the upper part of the McKenzie Member of the Mifflintown Formation in all four sections in which $O z$. snajdri occurs (Crabbottom - Fig. 5, Moyer Gap - Fig. 7, Keyser Reservoir - Fig. 10, Judy Gap - Fig. 11). This position places the first occurrence of $\mathrm{Oz}$. snajdri in the Homerian Stage in the Appalachian Basin. Viira \& Aldridge (1998) assigned all Oz. snajdri photographed by Helfrich (1975) to Oz. snajdri snajdri (Fig. 9D-F). Helfrich (1975) extended his Sp. snajdri zone to the top of the Williamsport Formation, however, the highest occurrence of the species is in the underlying McKenzie Member of the Mifflintown Formation. The top of this unzoned interval is placed at the first occurrence of Ozarkodina bohemica longa and contains all of the strata assigned to the unzoned interval and the Sp. snajdri Zone by Helfrich (1975).

\section{Ozarkodina bohemica Interval Zone (modified from Slavík 2014)}

Originally identified as Spathognathodus tillmani by Helfrich (1975), Jeppsson in Calner \& Jeppsson (2003) classified the name Sp. tillmani as a nomen dubium and introduced the name Ozarkodina bohemica longa including in its description specimens that were originally classified as Sp. tillmani by Helfrich (1975). The original diagnosis of $\mathrm{Oz} . \mathrm{b}$. longa that differentiated it from Ozarkodina bohemica bohemica was the greater length to height ratio of the blade in $O z$. $b$. longa. Many of the specimens identified as Sp. tillmani in the collection have a high length-to-width ratio (Fig. $9 \mathrm{H}-\mathrm{K}$ ), and are referred to herein as $\mathrm{Oz}$. bohemica longa. One significant exception is the holotype (Fig. 9G), which is much taller with a smaller blade length and is better classified as Ozarkodina bohemica bohemica. Unfortunately, Jeppsson in Calner \& Jeppsson (2003) did not give a specific length-to-height ratio to be used to distinguish $O z$. $b$. longa from $\mathrm{Oz}$. b. bohemica. This lack of taxonomic precision, combined with apparent geographic variability in the order of conodont lowest occurrences within the upper part of the Homerian Stage, led Slavík (2014) to use the $O z$. bohemica Interval Zone instead of the $O z$. bohemica longa and K. ortus absidata zones (Fig. 3). Slavík (2014) designated the disappearance of $O z$. sagitta sagitta as the base of the Oz. bohemica Interval Zone, but since $O z$. s. sagitta has not been recovered in the east-central Appalachian Basin, we instead use the first occurrence of $\mathrm{Oz}$. bohemica longa or $\mathrm{Oz}$. bohemica bohemica, whichever is lowest, as the marker for the base of the Oz. bohemica Interval Zone. The original definition of the top of the zone was the first occurrence of Kockelella crassa. Once again, this species does not occur in Helfrich's collection, and therefore the top of this zone is difficult to define in the study area.

The $O z$. bohemica Interval Zone is correlative with the $O z$. bohemica longa and $K$. ortus absidata zones of Cramer et al. (2011b) and McAdams et al. (2019) spanning the upper part of the Homerian Stage and is correlative with the entirety of the Sp. tillmani Zone as defined by Helfrich (1975). The lowest occurrence of the Oz. bohemica I.Z. is at the base of Wills Creek Formation (Crabbottom - Fig. 5, Judy Gap - Fig. 11) and the zone extends into roughly the middle of the Wills Creek Formation. The collection contains $\mathrm{Oz}$. bohemica longa, Oz. bohemica bohemica, and Ozarkodina confluens densidentata within this interval. Ozarkodina confluens highlandensis (Figs 9, 12, 13) first occurs within the uppermost part of this interval zone. The name Spathognathodus primus multidentatus Helfrich 1975 (Fig. 13) has priority over Spathognathodus primus densidentatus Viira (1983) [Ozarkodina confluens densidentata], however, for the same reasons as discussed for Sp. tillmani by Jeppsson in Calner \& Jeppsson (2003), $S p$. primus multidentatus is a nomen dubium and is referred to herein as Ozarkodina confluens densidentata (Jeppsson 1969, Helfrich 1975, Viira 1983, Jeppsson et al. 1995, Calner \& Jeppsson 2003). The first occurrence of Oz. c. densidentata in both the Gotland and East Baltic succession is within the $\mathrm{Oz}$. bohemica I.Z. of the upper Homerian and this matches the occurrence in all sections from 


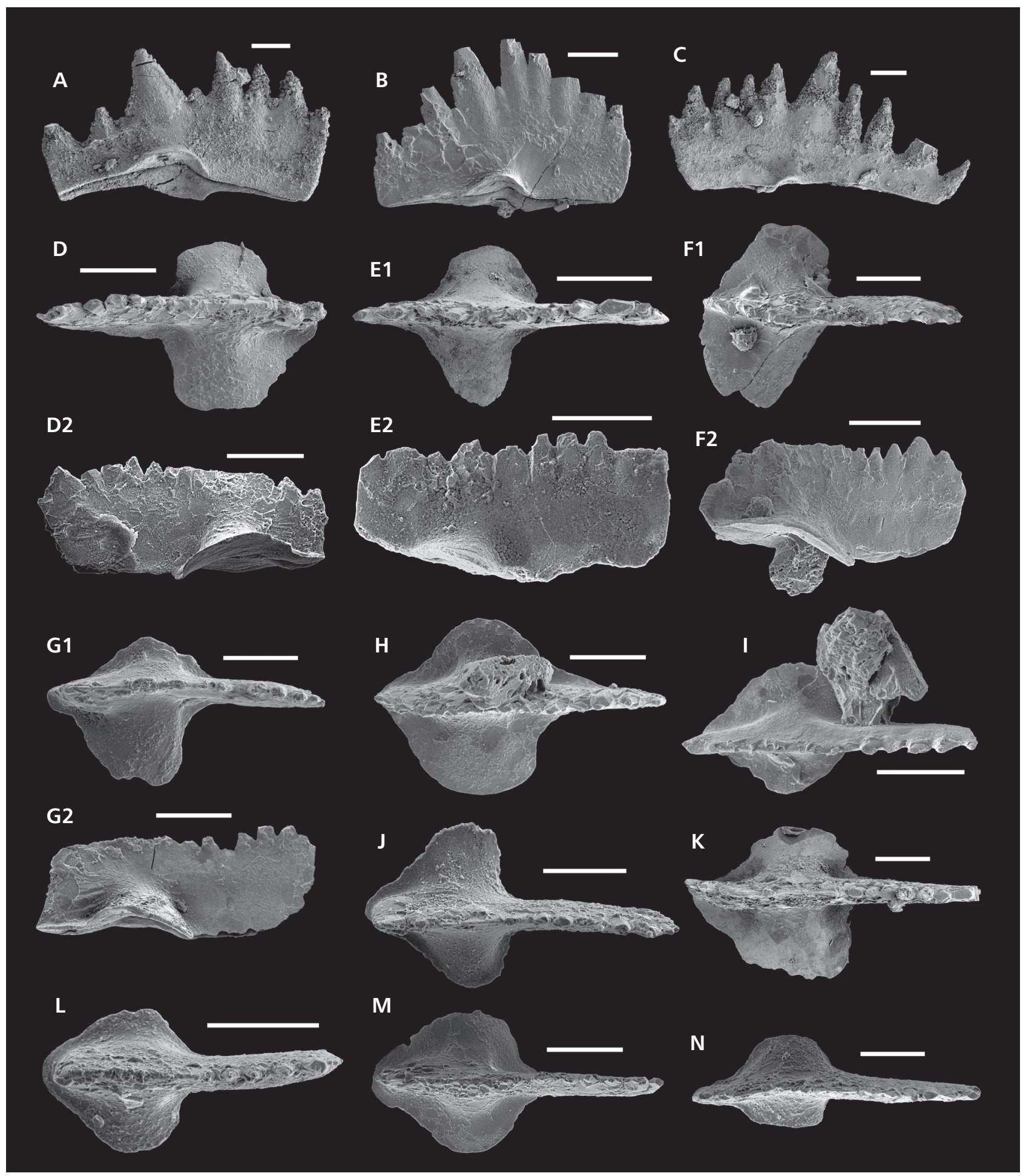

Figure 12. A-C - Ozarkodina confluens highlandensis (Helfrich, 1975); A - Crabbottom Section, Wills Creek Formation (CB-WC15) [VPIL 1146] paratype (Helfrich 1975, pl. 14, fig. 26); B - Pinto Section, Wills Creek Formation (P-WC22B) [VPIL 1139] paratype (Helfrich 1975, pl. 14, fig. 11); C - Crabbottom Section, Wills Creek Formation (CB-WC15) [VPIL 1147] paratype (Helfrich 1975, pl. 14, fig. 28). D-N - Ozarkodina crispa (Walliser, 1964); D - Judy Gap Section, Wills Creek Formation (JG-16) [VPIL 1429]; E - Judy Gap Section, Wills Creek Formation (JG-16B) [VPIL 1431]; F - Judy Gap Section, Wills Creek Formation (JG-16) [VPIL 1429]; G - Judy Gap Section, Wills Creek Formation (JG-16B) [VPIL 1431]; H - Judy Gap Section, Wills Creek Formation (JG-16) [VPIL 1429]; I - Judy Gap Section, Wills Creek Formation (JG-16) [VPIL 1429]; J - Judy Gap Section, Wills Creek Formation (JG-16B) [VPIL 1431]; K - Judy Gap Section, Wills Creek Formation (JG-16B) [VPIL 1431]; L - Judy Gap Section, Wills Creek Formation (JG-16B) [VPIL 1431]; M - Judy Gap Section, Wills Creek Formation (JG-16) [VPIL 1429BB]; N - Judy Gap Section, Wills Creek Formation (JG-16) [VPIL 1128] (Helfrich 1975, pl. 14, fig. 2). Scale bars $=100$ microns. 
which it was recovered in the study area (Crabbottom Fig. 5, Judy Gap - Fig. 11, Pinto - Fig. 14).

The identification of the $\mathrm{Oz}$. bohemica Interval Zone marks the largest change to global chronostratigraphic correlation in the study area. Helfrich's (1975) original correlation of his Sp. tillmani Zone with Walliser's (1964) latialata Zone was not based on the occurrence of any of the zonal indicators of the latialata Zone within the study area but rather the fact that this represented an interval above Oz. snajdri and below Ozarkodina crispa, both of which do occur in the study area. However, the presence of $\mathrm{Oz}$. bohemica longa, Oz. bohemica bohemica, and $O z$. c. densidentata clearly demonstrates a Homerian position for these strata. The result is that the occurrence of $\mathrm{Oz}$. snajdri in the studied sections is among the chronostratigraphically lowest yet recovered globally and that the lower half of the Wills Creek Formation does not represent the Ludfordian Stage of the Ludlow Series, but rather, the Homerian Stage of the Wenlock Series.

\section{Ozarkodina crispa Zone (Walliser 1964)}

The Ozarkodina crispa Zone of Walliser (1964) is a taxon-range zone that corresponds to the total range of Oz. crispa. Whereas the disappearance of Oz. crispa was once considered to be a marker for the base of the Pridoli Series, it is now clear that $O z$. crispa persists into the lower part of the Pridoli, and as a result, the LudlowPridoli boundary is now placed within the upper part of the Oz. crispa Zone (Corradini et al. 2015, McAdams et al. 2019). Specimens of Oz. crispa in the collection exhibit a great degree of morphological variability (Figs $12,13)$, and the collection clearly contains all of the morphotypes illustrated by Viira \& Aldridge (1998) from the East Baltic succession. Ozarkodina eosteinhornensis sensu lato appears in the upper part of the range of $\mathrm{Oz}$. crispa within the studied sections and matches well with other co-occurrence data of these two species globally (Viira \& Aldridge 1998, Kaljo et al. 2015).

The first occurrence of Oz. crispa is within the middle part of the Wills Creek Formation in all three locations that contain the Wills Creek (Crabbottom - Fig. 5, Judy Gap - Fig. 11, Pinto - Fig. 14). Surprisingly, at Crabbottom (Fig. 5), Oz. crispa appears immediately above the last appearances of both $\mathrm{Oz}$. b. bohemica and $\mathrm{Oz}$. $b$. longa, indicating that there is a substantial gap in the stratigraphic record somewhere near the middle of the Wills Creek Formation at this locality. This hiatus likely spans the entire Gorstian Stage and most of the Ludfordian Stage, likely including the mid-Ludfordian Lau Event and Excursion (Jeppsson et al. 2007, Kozłowski 2015, Mergl et al. 2018). However, this gap offers an explanation for the complete lack of all typical Ludlow conodonts from the east-central Appalachian Basin (e.g., Kockelella crassa, Kockelella variabilis, Ancoradella ploeckensis, Polygnathoides siluricus, Pedavis latialata). It is unclear how far this hiatus extends in any direction outside the immediate area studied herein. The last occurrence of $O z$. crispa is above the first occurrence of $\mathrm{Oz}$. eosteinhornensis s.l. within the Tonoloway Formation.

\section{Ozarkodina eosteinhornensis sensu lato Interval Zone (Corriga \& Corradini 2009)}

The base of the Ozarkodina eosteinhornensis sensu lato Interval Zone is placed at the last occurrence of Oz. crispa and the top is placed at the first occurrence of Oulodus elegans detortus, which does not occur in Helfrich's collection. The lowest occurrence of $\mathrm{Oz}$. eosteinhornensis s.l. is 24.29 meters above the base of the Tonoloway Formation at Crabbottom (Fig. 5). A single specimen of Oulodus elegans elegans was recovered 86.38 meters above the base of the Tonoloway Formation at Pinto (Fig. 14), coincident with the first occurrence of $O z$. eosteinhornensis s.l. in this section. Homeognathodus peniculus (Fig. 13N, O) occurs in one sample 93.06 meters above the base of the Tonoloway Formation at Pinto (Fig. 14). These three conodont species all occur within the Tonoloway Formation and provide a clear demonstration of the lower part of the Pridoli Series. However, the Helfrich collection does not contain conodonts indicative of the base of the Devonian System within this unit.

\section{Conclusions}

The re-examination of the conodont collection of C.T. Helfrich (Helfrich 1972, 1975, 1978, 1980) allows improved global correlation of the Silurian strata within the east-central Appalachian Basin (Fig. 15). A total of six conodont zones/zonal groups/interval zones can be

Figure 13. A-E - Ozarkodina crispa (Walliser, 1964); A - Crabbottom Section, Tonoloway Formation (CB-UT3) [VPIL 1133] (Helfrich 1975, pl. 14, fig. 19); B - Crabbottom Section, Tonoloway Formation (CB-T1A) [VPIL 1134] (Helfrich 1975, pl. 14, fig. 21); C - Crabbottom Section, Tonoloway Formation (CB-UT3) [VPIL 1417]; D - Crabbottom Section, Tonoloway Formation (CB-UT3) [VPIL 1131] (Helfrich 1975, pl. 14, fig. 9); E - Crabbottom Section, Tonoloway Formation (CB-UT3) [VPIL 1129] (Helfrich 1975, pl. 14, fig. 3). • F - Ozarkodina confluens confluens (Branson \& Mehl, 1933), Moyer Gap Section, McKenzie Member, Mifflintown Formation (MG-13) [VPIL 1347]. G-I - Ozarkodina confluens densidentata 


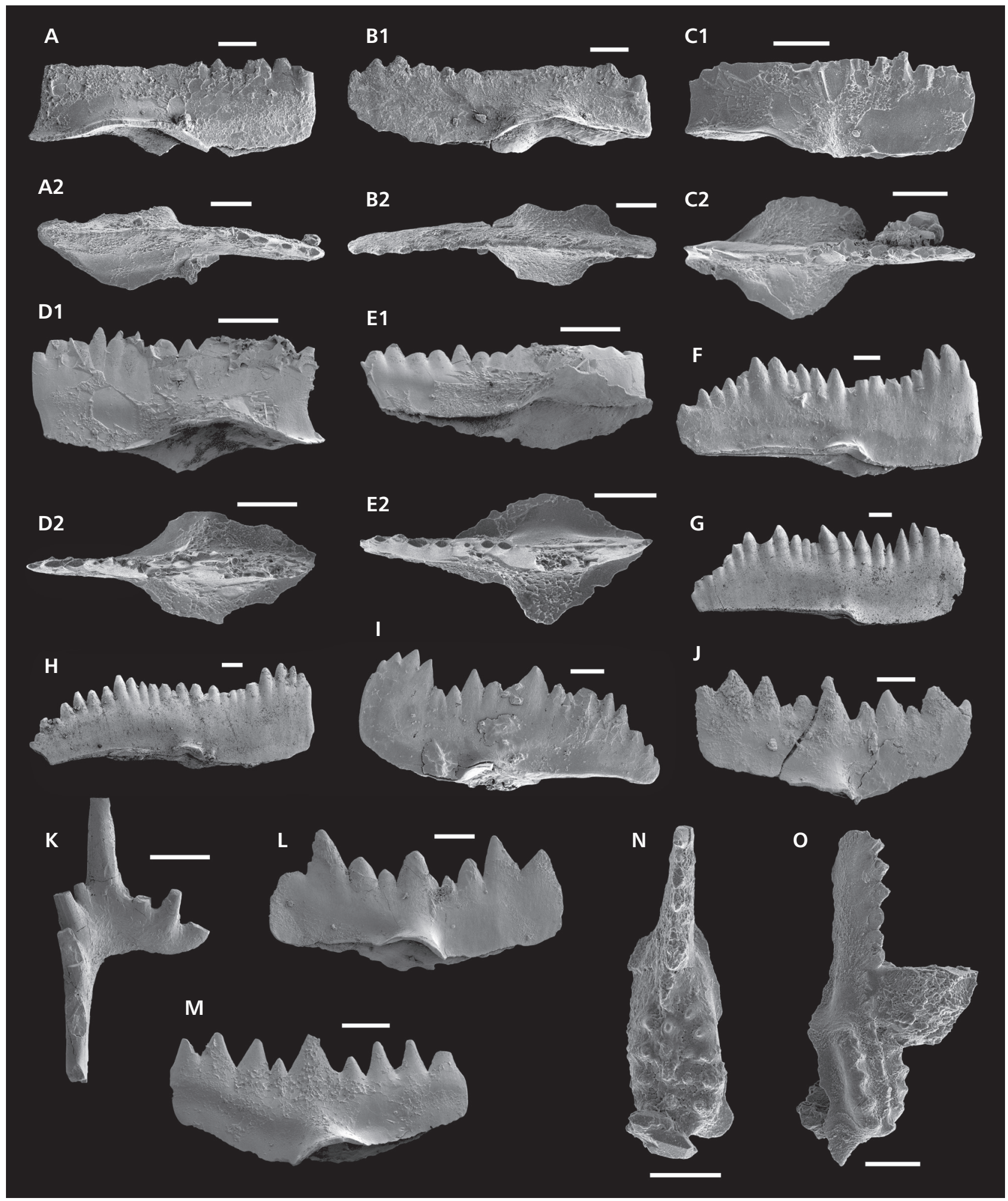

(Viira, 1983); G - Crabbottom Section, Wills Creek Formation (CB-WC1D) [VPIL 1152] (Helfrich 1975, pl. 13, fig. 15); H - Crabbottom Section, Wills Creek Formation (CB-WC1DUB) [VPIL 1155] (Helfrich, 1975, pl. 16, fig. 26); I - Crabbottom Section, Wills Creek Formation (CB-WC1) [VPIL 1388]. • J-M - Ozarkodina eosteinhornensis sensu lato (Walliser, 1964); J - Pinto Section, Tonoloway Formation (P-T19C) [VPIL 1447]; L - Pinto Section, Tonoloway Formation (P-T19C) [VPIL 1447]; M - Judy Gap Section, Tonoloway Formation (JG-32) [VPIL 1438].・K - Oulodus elegans elegans(Walliser, 1964), Pinto Section, Tonoloway Formation (P-T19C) [VPIL 0945] (Helfrich 1975, pl. 15, fig. 14). • N, O - Homeognathodus peniculus Denkler \& Harris, 1988b; N - Pinto Section, Tonoloway Formation (P-T21B) [VPIL 1286] (Helfrich 1975, pl. 16, fig. 2); O - Pinto Section, Tonoloway Formation (P-T21B) [VPIL 1285] (Helfrich 1975, pl. 16, fig. 1). Scale bars $=100$ microns. 


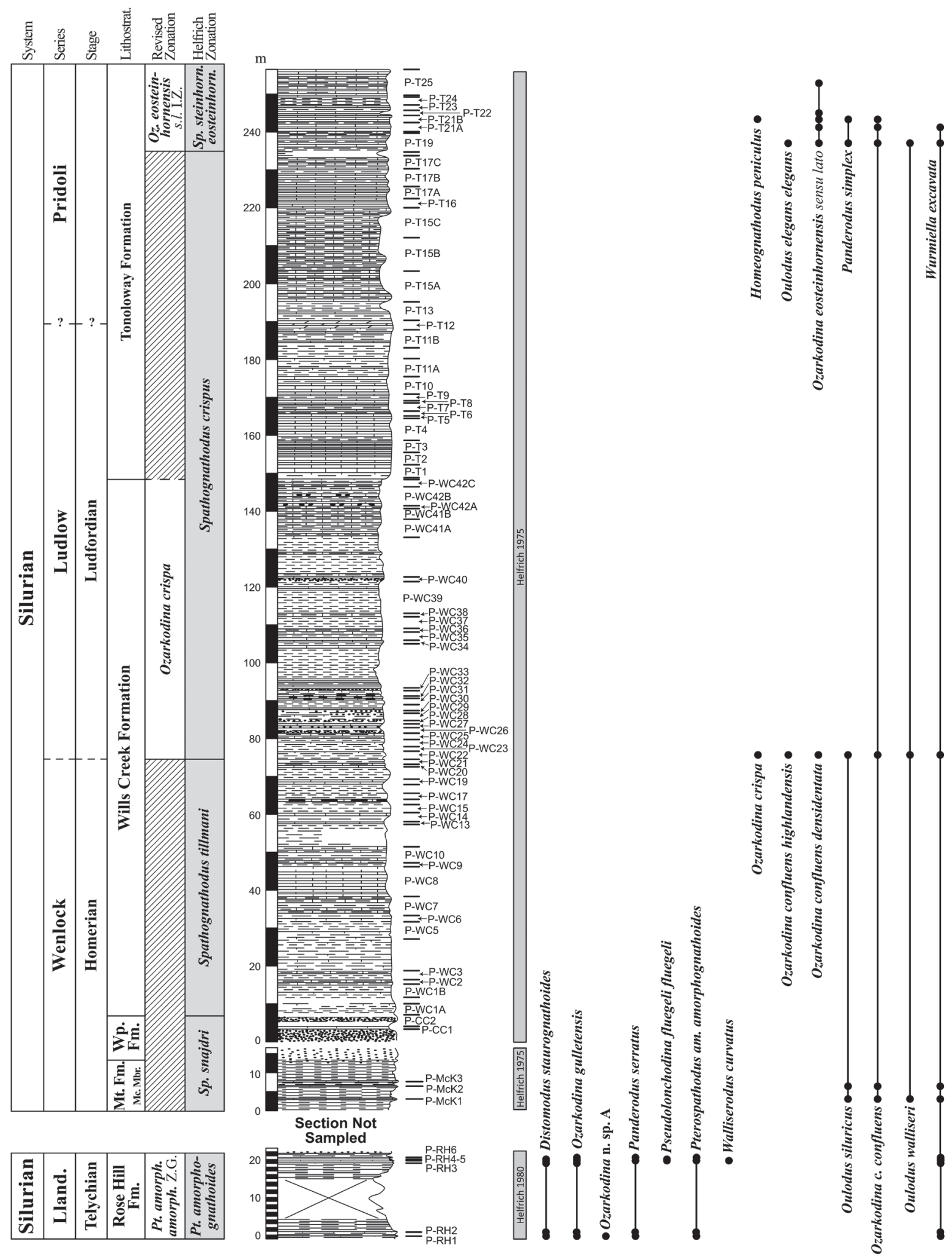

Figure 14. Stratigraphic column for the Pinto Section, Alleghany County, Maryland, combined from Helfrich (1980) and Helfrich (1975). The original biozonations of Helfrich are shown against the new biozonation designations made herein. Lithologic key can be found in the caption to Fig. 5. Diagonal hatching in the biozone column indicates an unzoned interval due to a lack of diagnostic fauna. Abbreviations: Lland. - Llandovery; Mc. Mbr. - McKenzie Member; Mt. Fm. - Mifflintown Formation; Wp. Fm. - Williamsport Formation; amorph. - amorphognathoides; eosteinhorn. eosteinhornensis; Pt. - Pterospathodus; Sp. - Spathognathodus; steinhorn. - steinhornensis; I.Z. - Interval Zone; Z.G. - Zonal Group. 
Figure 15. Comparison of chronolitho-biostratigraphic correlation between Helfrich (1975) and this study. The revised chart at bottom illustrates the position of global chronostratigraphic boundaries within the lithostratigraphic nomenclature of the east-central Appalachian Basin. Abbreviations: N.Y. - New York State, USA; Llan. - Llandovery; Lud. Ludlow; Ludf. - Ludfordian; Pri. Pridoli; Shein. - Sheinwoodian; Tely. - Telychian; eostein. eosteinhornensis; K. - Kockelella; Oz. - Ozarkodina; Pt. - Pterospathodus; s.l. - sensu lato; Sp. Spathognathodus; I.Z. - Interval Zone; Z.G. - Zonal Group.
Helfrich (1975) Chrono-Bio-Lithostratigraphy

\begin{tabular}{|c|c|c|c|c|c|c|}
\hline \multirow[b]{2}{*}{ 焉 } & \multicolumn{2}{|c|}{ Series } & \multirow{2}{*}{\multicolumn{2}{|c|}{$\begin{array}{l}\text { Wills Mountain } \\
\text { Anticiline } \\
\text { Lithostratigraphy }\end{array}$}} & \multirow[b]{2}{*}{$\begin{array}{l}\text { Appalachian Basin } \\
\text { Conodont Zones } \\
\text { (from Helfrich - 1975) }\end{array}$} & \multirow[b]{2}{*}{$\begin{array}{l}\text { European } \\
\text { Conodont Zones } \\
\text { (Walliser - 1964) }\end{array}$} \\
\hline & 苟 & $\underset{\dot{z}}{\dot{z}}$ & & & & \\
\hline \multirow{9}{*}{ 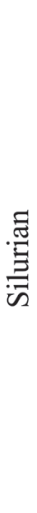 } & $\dot{\vec{D}}$ & \multirow{6}{*}{ 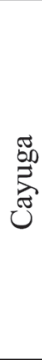 } & \multicolumn{2}{|c|}{ Tonoloway Formation } & Sp. steinhornensis eosteinhornensis & eosteinhornensis \\
\hline & & & & & Spathognathodus crispus & crispus \\
\hline & \multirow{4}{*}{ 旁 } & & \multicolumn{2}{|c|}{ Wills Creek Formation } & Spathognathodus tillmani & latialatus \\
\hline & & & \multicolumn{2}{|r|}{$\begin{array}{l}\text { Williamsport Formation } \\
\text { Bloomsburg Formation }\end{array}$} & Spathognathodus snaidri & siluricus snajdri \\
\hline & & & \multirow{4}{*}{ 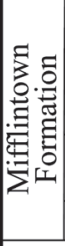 } & \multirow{2}{*}{ McKenzie Member } & Unzoned Interval & ploeckensis \\
\hline & & & & & Spathognathodus bicornutus & crassa \\
\hline & \multirow{3}{*}{ 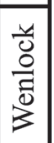 } & \multirow{3}{*}{ 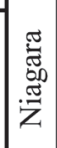 } & & Cosner Gap Member & Spathognathodus sagitta bohemicus & sagitta \\
\hline & & & & $\begin{array}{l}\text { Lower Hematitic Member } \\
{[\text { Keefer Member }]}\end{array}$ & & \multirow{2}{*}{ patula } \\
\hline & & & & ose Hill Formation & & \\
\hline
\end{tabular}

Revised Chrono-Bio-Lithostratigraphy

\begin{tabular}{|c|c|c|c|c|c|c|}
\hline$\frac{E}{\sum_{0}^{2}}$ & हैं & 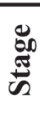 & \multicolumn{2}{|c|}{$\begin{array}{c}\text { Wills Mountain } \\
\text { Anticiline } \\
\text { Lithostratigraphy }\end{array}$} & $\begin{array}{c}\text { Revised } \\
\text { Appalachian } \\
\text { Conodont Zones }\end{array}$ & $\begin{array}{l}\text { Appalachian Basin } \\
\text { Conodont Zones } \\
\text { (from Helfrich - 1975) }\end{array}$ \\
\hline \multirow{9}{*}{ 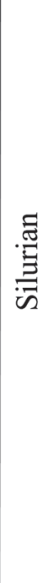 } & 言 & & \multirow{2}{*}{\multicolumn{2}{|c|}{ Tonoloway Formation }} & $\begin{array}{l}\text { Oz. eosteinhornensis } \\
\text { sensu lato Interval Zone }\end{array}$ & $\begin{array}{l}\text { Spathognathodus } \\
\text { steinhornensis eosteinhornensis }\end{array}$ \\
\hline & تُ & ن & & & \multirow{2}{*}{$\begin{array}{c}\text { Oz. crispa } \\
-\overline{\text { Oz. }} \overline{\text { bohemica }}-\overline{\mathrm{I}} . \mathrm{Z}\end{array}$} & Spathognathodus crispus \\
\hline & \multirow{5}{*}{$\begin{array}{l}\frac{y}{8} \\
0 \\
0 \\
0\end{array}$} & \multirow{3}{*}{ 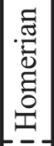 } & \multicolumn{2}{|c|}{ Wills Creek Formation } & & Spathognathodus tillmani \\
\hline & & & \multicolumn{2}{|r|}{$\begin{array}{c}\text { Williamsport Formation } \\
\text { Bloomsburg Formation }\end{array}$} & \multirow{2}{*}{ Unzoned Interval } & Spathognathodus snajdri \\
\hline & & & \multirow{4}{*}{ 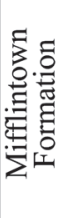 } & \multirow{2}{*}{ McKenzie Member } & & Unzoned Interval \\
\hline & & $\dot{\Xi}$ & & & Oz. bicornuta & Spathognathodus bicornutus \\
\hline & & $\approx$ & & Cosner Gap Member & K. walliseri Zonal Group & Spathognathodus sagitta bohemicus \\
\hline & \multirow{2}{*}{ 离 } & \multirow[b]{2}{*}{$\stackrel{\overrightarrow{0}}{\oplus}$} & & $\begin{array}{l}\text { Lower Hematitic Member } \\
\text { [Keefer Member] }\end{array}$ & \multirow{2}{*}{$\begin{array}{c}\text { Pt. amorphognathoides } \\
\text { amorphognathoides } \\
\text { Zonal Group }\end{array}$} & \\
\hline & & & & ose Hill Formation & & \\
\hline
\end{tabular}

identified in the collection spanning the upper Telychian Stage (Llandovery Series) to at least the lower part of the Pridoli Series. A major stratigraphic gap is identified that spans most of the Ludlow Series from the lower part of the Gorstian Stage to the upper part of the Ludfordian Stage. This gap explains both the need to lower the global chronostratigraphic correlation of the McKenzie Member of the Mifflintown Formation as well as the lack of even the most cosmopolitan of Ludlow species from the collection.

The Llandovery-Wenlock boundary can be confidently placed within the Lower Hematitic Member of the Mifflintown Formation. The base of the Homerian Stage is more difficult to correlate globally, and an unzoned interval in this part of the Appalachian Basin can only refine its position to somewhere within the middle part of the McKenzie Member of the Mifflintown Formation. There are no clear indicators for the base of the Ludlow Series (Gorstian Stage), nor for the base of the Ludfordian Stage of the Ludlow Series. Within the middle part of the Wills Creek Formation an abrupt transition occurs from an upper Homerian fauna to an upper Ludfordian fauna. The base of the Pridoli can be narrowed down to a small window within the lowermost part of the Tonoloway Formation. There are no indicators of the base of the Devonian System within the collection.

\section{Acknowledgments}

This work was partially supported by grants from the American Chemical Society - Petroleum Research Fund (Grant \# 
53196-DNI8) and the National Science Foundation (Grant \# CAREER-1455030) to B.D. Cramer. The authors are grateful to S. Llyn Sharp, Museum of Geosciences Coordinator at Virginia Tech (Virginia Polytechnic Institute and State University), for kindly providing access to the Helfrich collection and Tiffany Adrain, Special Collections Manager at the University of Iowa Paleontology Repository, for assisting in the logistics of borrowing it. The thorough and thoughtful reviews of Mark A. Kleffner (The Ohio State University - Lima) and Ladislav Slavík (Institute of Geology of the Czech Academy of Sciences) greatly improved this paper and we thank David K. Loydell (University of Portsmouth) for handling the manuscript.

\section{References}

AldRidge, R.J. 1972. Llandovery conodonts from the Welsh Borderland. Bulletin of the British Museum (Natural History) Geology 22, 125-231.

AldRIDGE, R.J. 1975. The Silurian conodont Ozarkodina sagitta and its value in correlation. Palaeontology 18(2), 323-332.

AldRIDGE, R.J. 1985. Conodonts of the Silurian System from the British Isles, 68-92. In Higgins, A.C. \& Austin, R.L. (eds) A stratigraphical index of conodonts. Ellis Horwood Ltd., Chichester, England.

Aldridge, R.J. \& SchÖNLAUb, H.P. 1989. Conodonts, 264-267. In Holland, C.H. \& Bassett, M.G. (eds) A global standard for the Silurian System. National Museum of Wales Geological Series No. 9. Cardiff.

Aldridge, R.J. \& von Bitter, P. 2009. The Pander Society: a brief history at Forty (1967-2007). Palaeontographica Americana 62, 11-21.

Barrick, J.E. \& Klapper, G. 1976. Multielement (late Llandoverian-Wenlockian) conodonts of the Clarita Formation, Arbuckle Mountains, Oklahoma, and phylogeny of Kockelella. Geologica et Palaeontologica 10, 59-100.

Berry, W.B.N. \& Boucot, A.J. 1970. Correlation of the North American Silurian rocks. Geological Society of America Special Paper 102, 1-289. DOI 10.1130/SPE102-p1

Bischoff, G.C.O. 1986. Early and middle Silurian conodonts from Midwestern New South Wales. Courier Forschungsinstitut Senckenberg 89, 1-337.

Branson, E.B. \& Meht, M.G. 1933. Conodonts from the Bainbridge (Silurian) of Missouri, Conodont Studies Number 1. The University of Missiouri Studies: A Quarterly of Research 8, 39-52.

Brett, C.E., Tepper, D.H., Goodman, W.M., Loduca, S.T. \& ECKERT, B.-Y. 1995. Revised stratigraphy and correlation of the Niagaran Provincial Series (Medina, Clinton and Lockport Groups) in the type area of western New York. United States Geological Survey Bulletin 2086, 1-66.

Calner, M. \& Jeprsson, L. 2003. Carbonate platform evolution and conodont stratigraphy during the middle Silurian Mulde Event, Gotland, Sweden. Geological Magazine 140, 173-203. DOI 10.1017/S0016756802007070

Carls, P., Slavík, L. \& Valenzuela-Ríos, J.I. 2007. Revisions of conodont biostratigraphy across the Silurian-Devonian boundary. Bulletin of Geosciences 82, 145-164.

DOI 10.3140/bull.geosci.2007.02.145

Corradini, C. \& Serpagli, E. 1999. A Silurian conodont zonation from late Llandovery to end Pridoli in Sardinia. Bollettino della Società Paleontologica Italiana 38, 255-273.

Corradini, C., Corriga, M.G., Männik, P. \& Schönlaub, H.P. 2015. Revised conodont stratigraphy of the Cellon section (Silurian, Carnic Alps). Lethaia 48, 56-71.

DOI 10.1111/let.12087

Corriga, M.G. \& Corradini, C. 2009. Upper Silurian and lower Devonian conodonts from the Monte Cocco II section (Carnic Alps, Italy). Bulletin of Geosciences 84, 155-168. DOI 10.3140/bull.geosci.1112

Cramer, B.D., Brett, C.E., Melchin, M.J., Männik, P., Kleffner, M.A., McLaughlin, P.I., Loydell, D.K., Munnecke, A., Jeppsson, L., Corradini, C., Brunton, F.R. \& Saltzman, M.R. 2011b. Revised correlation of Silurian Provicial Series of North America with global and regional chronostratigraphic units and $\delta^{13} \mathrm{C}_{\text {carb }}$ chemostratigraphy. Lethaia 44, 185-202. DOI 10.1111/j.1502-3931.2010.00234.x

Cramer, B.D., Kleffner, M.A., Brett, C.E., Mclaughlin, P.I., Jeppsson, L., Munnecke, A. \& Samtleben, C. 2010. Paleobiogeography, high-resolution stratigraphy and the future of Paleozoic biostratigraphy: Fine-scale diachroneity of the Wenlock (Silurian) conodont Kockelella walliseri. Palaeogeography, Palaeoclimatology, Palaeoecology 294, 232-241. DOI 10.1016/j.palaeo.2010.01.002

Cramer, B.D., Munnecke, A., Schofield, D.I., Haase, K.M. \& HaAse-Schramm, A. 2011a. A revised ${ }^{87} \mathrm{Sr} /{ }^{86} \mathrm{Sr}$ curve for the Silurian: Implications for global ocean chemistry and the Silurian timescale. Journal of Geology 119, 335-349.

DOI 10.1086/660117

Denkler, K.E. \& Harris, A.G. 1988a. Conodont-based determination of the Silurian-Devonian boundary in the Valley and Ridge Province, northern and central Appalachians. United Stated Geological Survey Bulletin 1937, B1-B13.

Denkler, K.E. \& Harris, A.G. 1988b. Homeognathodus peniculus (Conodonta), a new earliest Pridolian index species, and the Ludlovian-Pridolian boundary in the central Appalachian Basin. United States Geological Survey Bulletin 1937, C1-C10.

Ettensohn, F.R. \& Brett, C.E. 2002. Stratigraphic evidence from the Appalachian Basin for continuation of the Taconic Orogeny into early Silurian time. Physics and Chemistry of the Earth 27, 279-288. DOI 10.1016/S1474-7065(01)00010-9

Goodman, W.M. \& Brett, C.E. 1994. Roles of eustasy and tectonics in development of Silurian stratigraphic architecture of the Appalachian foreland basin, 147-169. In DenNison, J.M. \& EtTensohn, F.R. (eds) Tectonic and eustatic controls on sedimentary cycles. Society of Economic and Petroleum Mineralogists, Concepts in sedimentology and paleontology 4. DOI 10.2110/csp.94.04.0147

Helfrich, C.T. 1972. Silurian conodonts from the Wills Mountain Anticline, Virginia, West Virginia, and Maryland. 402 pp. Ph.D. thesis, Virginia Polytechnic Institute and State University. Blacksburg, Virginia. 
Helfrich, C.T. 1975. Silurian conodonts from the Wills Mountain Anticline, Virginia, West Virginia, and Maryland. Geological Society of America Special Paper 161, 1-82. DOI 10.1130/SPE161-p1

Helfrich, C.T. 1978. A conodont fauna from the Keyser Limestone of Virginia and West Virginia. Journal of Paleontology 52, 1133-1142.

HeLfrich, C.T. 1980. Late Llandovery-early Wenlock conodonts from the upper part of the Rose Hill and basal part of the Mifflintown Formations, Virginia, West Virginia, and Maryland. Journal of Paleontology 54, 557-569.

HibBard, J. 2000. Docking Carolina: Mid-Paleozoic accretion in the southern Appalachians. Geology 28, 127-130. DOI 10.1130/0091-7613(2000)28<127:DCMAIT > 2.0.CO;2

Horvath, A.L. 1969. Relationships of middle Silurian strata in Ohio and West Virginia. The Ohio Journal of Science 69, 321-342.

JePpSSON, L. 1969. Notes on some Upper Silurian multielement conodonts. GFF 91, 12-24.

DOI $10.1080 / 11035896909448421$

Jeppsson, L. 1997. A new latest Telychian, Sheinwoodian and early Homerican (early Silurian) standard conodont zonation. Transactions of the Royal Society of Edinburgh: Earth Sciences 88, 91-114.

DOI 10.1017/S0263593300006854

Jeppsson, L. 2005. Conodont-based revisions of the Late Ludfordian on Gotland, Sweden. GFF 127, 273-282.

DOI $10.1080 / 11035890501274273$

Jeppsson, L. \& Aldridge, R.J. 2000. Ludlow (late Silurian) oceanic episodes and events. Journal of the Geological Society, London 157, 1137-1148.

DOI 10.1144/jgs.157.6.1137

Jeppsson, L., Aldridge, R.J. \& Dorning, K.J. 1995. Wenlock (Silurian) oceanic episodes and events. Journal of the Geological Society, London 152, 487-498.

DOI 10.1144/gsjgs.152.3.0487

Jeppsson, L., Eriksson, M.E. \& Calner, M. 2006. A latest Llandovery to latest Ludlow high-resolution biostratigraphy based on the Silurian of Gotland - a summary. GFF 128, 109-114. DOI 10.1080/11035890601282109

Jeppsson, L., Talent, J.A., Mawson, R., Simpson, A.J., Andrew, A.S., Calner, M., Whitford, D.J., Trotter, J.A., SAndström, O. \& Caldon, H.-J. 2007. High-resolution Late Silurian correlations between Gotland, Sweden, and the Broken River region, NE Australia: Lithologies, conodonts, and isotopes. Palaeogeography, Palaeoclimatology, Palaeoecology 245, 115-137. DOI 10.1016/j.palaeo.2006.02.032

Kaljo, D., Einasto, R., Martma, T., Märss, T., Nestor, V. \& VIIRA, V. 2015. A bio-chemostratigraphical test of the synchroneity of biozones in the upper Silurian of Estonia and Latvia with some implications for practical stratigraphy. Estonian Journal of Earth Sciences 64, 267-283. DOI 10.3176/earth.2015.33

KLeffner, M.A. 1989. A conodont-based Silurian chronostratigraphy. Geological Society of America Bulletin 101, 904-912.

DOI 10.1130/0016-7606(1989)101<0904:ACBSC>2.3.CO;2
KLEFFNER, M.A. 1995. A conodont- and graptolite-based Silurian chronostratigraphy. SEPM Special Publication 53, 159-176. DOI 10.2110/pec.95.53.0159

Kleffner, M.A., Barrick, J.E., Ebert, J.R., Matteson, D.K. \& Karlsson, H.R. 2009. Conodont biostratigraphy and $\delta^{13} \mathrm{C}$ chemostratigraphy, and recognition of Silurian/Devonian boundary in the Cherry Valley, New York region of the Appalachian Basin. Palaeontographica Americana 62, 57-73.

KozŁowsKi, W. 2015. Eolian dust influx and massive whiting during the kozlowski/Lau Event: carbonate hypersaturation as a possible driver of the mid-Ludfordian Carbon Isotope Excursion. Bulletin of Geosciences 90, 807-840. DOI 10.3140/bull.geosci.1581

Männik, P. 1998. Evolution and taxonomy of the Silurian conodont Pterospathodus. Palaeontology 41, 1001-1050.

MänNik, P. 2007. An updated Telychian (late Llandovery, Silurian) conodont zonation based on Baltic faunas. Lethaia 40, 45-60. DOI 10.1111/j.1502-3931.2006.00005.x

Männik, P., Loydell, D.K., Nestor, V. \& NõlvaK, J. 2015. Integrated Upper Ordovician - lower Silurian biostratigraphy of the Grötlingbo-1 core section, Sweden. GFF 137, 226-244. DOI 10.1080/11035897.2015.1042032

Mathieson, D., Mawson, R., Simpson, A.J. \& Talent, J.A. 2016. Late Silurian (Ludlow) and Early Devonian (Pragian) conodonts from the Cobar Supergroup, western New South Wales, Australia. Bulletin of Geosciences 91, 583-652. DOI 10.3140/bull.geosci.1593

McAdams, N.E.B., Cramer, B.D., Bancroft, A.M., Melchin, M.J., Devera, J.A. \& Day, J.E. 2019. Integrated $\delta^{13} C_{\text {carb}}$, conodont, and graptolite Biochemostratigraphy of the Silurian from the Illinois Basin and stratigraphic revision of the Bainbridge Group. GSA Bulletin 131, 335-352. DOI 10.1130/B32033.1

Mergl, M., Frýda, J. \& Kubajko, M. 2018. Response of organophosphatic brachiopods to the mid-Ludfordian (late Silurian) carbon isotope excursion and associated extinction events in the Prague Basin (Czech Republic). Bulletin of Geosciences 93, 369-400. DOI 10.3140/bull.geosci.1710

Murphy, M.A., Valenzuela-Ríos, J.I. \& Carls, P. 2004. On classification of Pridoli (Silurian)-Lochkovian (Devonian) Spathognathodontidae (Conodonts). University of California, Riverside Campus Museum Contribution 6, 1-27.

Nicoll, R.S. \& ReXroad, C.B. 1968. Stratigraphy and conodont paleontology of the Salamonie Dolomite and Lee Creek Member of the Brassfield Limestone (Silurian) in southeastern Indiana and adjacent Kentucky. Indiana Department of Natural Resources Geological Survey Bulletin 40, 1-96.

Nowlan, G.S. 1995. Left hand column for correlation charts. Silurian Times 3, 7-8.

Pinet, N. 2016. Far-field effects of Appalachian orogenesis: A view from the craton. Geology 44, 83-86.

DOI 10.1130/G37356.1

Pollock, C.A., Rexroad, C.B. \& Nicoll, R.S. 1970. Lower Silurian conodonts from northern Michigan and Ontario. Journal of Paleontology 44, 743-764. 
Staví, L. 2014. Revision of the conodont zonation of the Wenlock-Ludlow boundary in the Prague Synform. Estonian Journal of Earth Sciences 63, 305-311.

DOI 10.3176/earth.2014.35

Sullivan, N.B., Mclaughlin, P.I., Brett, C.E., Cramer, B.D., Kleffner, M.A., Thomka, J.R. \& EmsBo, P. 2016. Sequence boundaries and chronostratigraphic gaps in the Llandovery of Ohio and Kentucky: The record of early Silurian paleoceanographic events in east-central North America. Geosphere 12, $1813-1832$. DOI 10.1130/GES01343.1

Sweet, W.C. \& Bergström, S.M. 1970. The generic concept in conodont taxonomy. North American Paleontological Convention, 1969, Proceedings $C, 157-173$.

Van Staal, C.R., Zagorevski, A., McNicoll, V.J. \& Rogers, N. 2014. Time-transgressive Salinic and Adacian orogenesis, magmatism and Old Red Sandstone sedimentation in Newfoundland. Geoscience Canada 41, 138-164.

DOI 10.12789/geocanj.2014.41.031

VIIRA, V. 1983. Upper Silurian Spathognathodus (Conodonts) from Estonia 41-71. In KlaAmann, E. (ed). Palaeontology of early Paleozoic of the East Baltic and Podolia. Academy of Sciences of the Estonian SSR, Institute of Geology. [in Russian with English summary]

VIIRA, V. \& Aldridge, R.J. 1998. Upper Wenlock to Lower Pridoli (Silurian) conodont biostratigraphy of Saaremaa, Estonia, and a correlation with Britain. Journal of Micropalaeontology 17, 33-50. DOI 10.1144/jm.17.1.33

WAID, C.B.T. \& CRAMER, B.D. 2017a. Global chronostratigraphic correlation of the Llandovery Series (Silurian System) in Iowa, USA, using high-resolution carbon isotope $\left(\delta^{13} \mathrm{C}_{\text {carb }}\right)$ chemostratigraphy and brachiopod and conodont biostratigraphy. Bulletin of Geosciences 92, 373-390.

DOI 10.3140/bull.geosci.1657

Waid, C.B.T. \& Cramer, B.D. 2017b. Telychian (Llandovery, Silurian) conodonts from the LaPorte City Formation of eastern Iowa, USA (East-Central Iowa Basin) and their implications for global Telychian conodont biostratigraphic correlation. Palaeontologia Electronica 20.2.39A, 1-37. DOI $10.26879 / 685$

Walliser, O.H. 1964. Conodonten des Silurs. Abhandlungen des Hessischen Landesamtes für Bodenforschung 41, 1-106. 